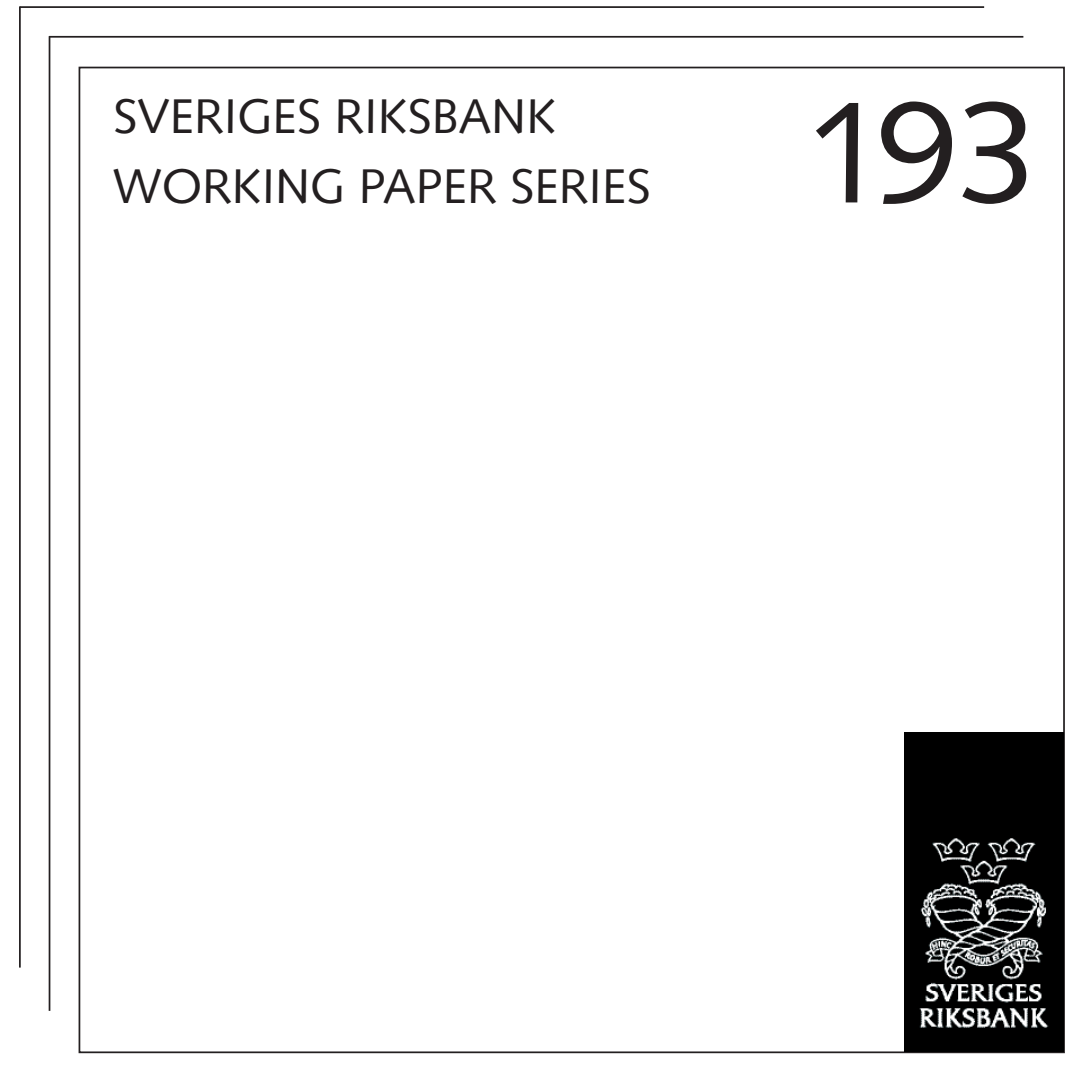

\title{
A Simultaneous Model of the Swedish Krona, the US Dollar and the Euro
}

Hans Lindblad and Peter Sellin 


\section{WORKING PAPERS ARE OBTAINABLE FROM}

Sveriges Riksbank • Information Riksbank • SE-103 37 Stockholm Fax international: +4687870526

Telephone international: +4687870100 E-mail: info@riksbank.se

The Working Paper series presents reports on matters in the sphere of activities of the Riksbank that are considered to be of interest to a wider public.

The papers are to be regarded as reports on ongoing studies and the authors will be pleased to receive comments.

The views expressed in Working Papers are solely the responsibility of the authors and should not to be interpreted as reflecting the views of the Executive Board of Sveriges Riksbank. 


\title{
A Simultaneous Model of the Swedish Krona, the US Dollar and the Euro
}

\author{
Hans Lindblad \\ Sveriges Riksdag \\ SE 10012 Stockholm
}

\author{
Peter Sellin* \\ Sveriges Riksbank \\ SE 10337 Stockholm
}

\author{
Sveriges Riksbank Working Paper Series \\ No. 193 \\ May 2006
}

\begin{abstract}
In this paper we simultaneously estimate the real exchange rates between the Swedish Krona, the US Dollar and the Euro. A prime candidate for explaining the exchange rate movements is relative potential output. Since this variable is unobservable, cyclical and potential output are estimated in an unobserved components framework together with a Phillips curve. Our empirical exchange rate results are in line with theory. Increases in relative potential output and the terms of trade strengthen the exchange rate, while a relative increase of the fraction of middle-aged people in the population and budget deficits depreciate the exchange rate. The estimates suggest that the recent deterioration of the relative budget situation for the US versus Europe is a prime candidate for explaining the USD/EUR exchange rate change lately.
\end{abstract}

KEY WORDS: Equilibrium real exchange rate, expectations augmented Phillips curve, unobserved-components model.

JEL CLASSIFICATION: C32, E31, F31, F41.

\footnotetext{
*We would like to thank Malin Adolfson, Lars Calmfors and seminar participants at Sveriges Riksbank, the National Institute of Economic Research and at AEA International Conference on Exchange rate econometrics spring 2005 for helpful coments. The views expressed in this paper are solely the resposibility of the authors and should not be interpreted as reflecting the views of the Executive Board of Sveriges Riksbank. E-mail: hans.lindblad@riksdagen.se and peter.sellin@riksbank.se
} 


\section{Introduction}

Sweden is a small open economy with exports and imports amounting to about 46 and 38 per cent of GDP respectively in 2004. Thus an important factor when analyzing the state of the Swedish economy is the value of the Krona (SEK) against other currencies. When analyzing exchange rates, the most common approach is to look at a bilateral exchange rate or at the currency of interest in relation to a weighted index of foreign currencies. Sweden's largest trading partner is the Euro area, which absorbs about 40 per cent of Sweden's exports. Thus the exchange rate vis-a-vis the Euro (EUR) is of natural interest. But since about 60 per cent of Swedish exports are destined elsewhere, the SEK and the EUR exchange rate against other currencies are also of great interest.

The main contribution of this paper is to simultaneously estimate the shortand long-run dynamics of the three real exchange rates between the SEK, the EUR and the US Dollar (USD).

The real exchange rate between two currencies shows how much output the home country has to spend in order to obtain one unit of foreign output. Usually, and this paper is no exception, the real exchange rate is expressed in terms of consumer goods. The real exchange rate between for instance the SEK and the USD can then be expressed as how many units of a Swedish consumption basket it takes to buy one unit of the US consumption basket. From this definition the real exchange rate can be written as the product of the nominal exchange rate and the ratio between the foreign and the domestic consumer price levels. ${ }^{1}$

According to theory, the real exchange rate is determined by a set of institutional and economic factors such as determinants to relative productivity, terms of trade, net foreign assets and openness (Masson, Kremers, and Horne, 1994; Lane and Milesi-Ferretti, 2004; and Bergvall, 2002). In previous empirical work, there is a voluminous literature that takes its starting point in some simple accounting relationships. This literature is reviewed in MacDonald (2000). Empirical testing of the more rigorous theoretical models in the new open macroeconomics literature is surveyed in Ghironi (2000) and Lane (2001).

Empirically it is usually thought that there exists a long-run relationship between the real exchange rate and a set of theoretically motivated explanatory variables. Lane and Milesi-Ferretti (2004), Bergvall (2002), and Nilsson (2002) estimate real exchange rate equations derived from new open economy models and find that the real exchange rate is cointegrated with relative GDP, the terms of trade (relative price between exported and imported goods and services), and net foreign assets. Alexius (2001) estimates a common trends model for the Nordic countries and finds that relative productivity is the most important determinant of long-run movements in the real exchange rate in all the countries investigated. Hjelm (2001) also finds that productivity shocks are the main

\footnotetext{
${ }^{1}$ The $(\log )$ real exchange rate between SEK and USD can be written as

$$
e^{s u}=c^{s u}+p^{u}-p^{s},
$$

where $c^{s u}$ is the $(\log )$ nominal SEK/USD exchange rate and $p$ is the (log) consumer price level. Superscript $u$ denotes the US and superscript $s$ Sweden.
} 
force driving the US real exchange rate relative to the UK, Germany and Japan. MacDonald and Marsh (1999) uses a purchasing power parity model augmented with an interest rate differential to simultaneously estimate the exchange rates between the US Dollar, the German D-Mark and the Japanese Yen. Their study highlights the complex interactions among the variables in a tri-polar exchange rate system.

A prime candidate explaining the development of an exchange rate is thus the relative trend productivity or relative trend output. When explaining the dynamics of the exchange rate the difference in the utilization of resources should then be of importance. Since both potential output and output gaps are not observable, actual output is often used as a proxy for the former and output minus an ad hoc trend as a proxy for the latter. An alternative is to use economic theory and define and estimate the output gap and potential output. We will define cyclical output in a standard Phillips-curve framework and estimate cyclical and potential output for each country in an unobserved components (UC) model and subsequently use these estimated variables in our exchange rate model. Other recent examples of UC-model applications are found in Lindblad (1997), Apel and Jansson (1999), Laubach (2001), and Turner et al. (2001).

\section{Theoretical discussion}

The theoretical background to our empirical exchange rate specification can be found in the new open macroeconomics literature, e.g. Lane and MilesiFerretti (2004). They set up a small open economy model, where consumers maximize lifetime utility subject to an intertemporal budget constraint and firms maximize profits. Household utility is a function of consumption and labor input. Consumers are assumed to consume both tradable and non-tradable goods and decide on consumption and labor supply. Firms produce a traded and a non-traded good and set prices in order to maximize profits. Solving the Lane and Milesi-Ferretti model gives the following long-run determinants of the real exchange rate: exogenous terms of trade shocks, net foreign assets, and relative production in the tradable sector. The intuition is quite straightforward, an increase in the terms of trade, net foreign assets or production in one country will raise income and stimulate consumption of traded goods. A higher level of consumption increases wealth and consumers will in response to this decrease labor supply in the non-tradable sector. ${ }^{2}$ A lower labor supply will reduce the production of non-traded goods and thus increase the relative price of nontradables and hence cause a real appreciation.

In the model described above the terms of trade effect is unambiguous through this wealth effect on the relative price of non-tradables: an increase will strengthen the real exchange rate. In other models the effect of a terms of trade shock on the real exchange rate can be theoretically ambiguous, depend-

\footnotetext{
${ }^{2}$ In the model, labor is for simplicity assumed only to be used in the non-tradable sector, reflecting the fact that labor is relatively more important in the production of non-traded goods.
} 
ing for example on whether or not there is a home consumption bias within the category of tradable goods as in Obstfeld and Rogoff (2004). A home bias implies that home-produced tradables have a greater weight than foreign-produced tradables in the consumption basket. A relative increase in the price of homeproduced tradables (improved terms of trade) will then have a greater impact on the consumer price index in the home country compared to the foreign country, leading to an appreciation of the real exchange rate. A foreign consumption bias would instead lead to a depreciation. Empirically a positive terms of trade shock has in most cases been found to lead to a significant appreciation of the real exchange rate (Dungey, 2002; Nilsson, 2002; and Lane and Milesi-Ferretti, 2004 ), which is consistent with a home-bias, although there are exceptions (see e.g. Alexius and Nilsson, 2000).

Regarding net foreign assets, Lane and Milesi-Ferretti (2004) conclude that international transfers, as reflected in a changing net foreign asset position, has an important effect on the relative price of non-traded to traded goods. An inflow of funds induce the now wealthier households to reduce their labor supply used in the production of non-traded goods. This will reduce the supply of (and at the same time increase the demand for) non-traded goods whose relative price will then rise, implying an appreciation of the real exchange rate. Hence, higher (lower) net foreign assets are related to a more appreciated (depreciated) real exchange rate. The theory does however not discuss what an optimal or equilibrium level of the net foreign asset position is.

A country's net foreign asset position is determined by its accumulated net savings. Since the savings ratios differ among cohorts of the population an important and presumably exogenous determinant of accumulated net savings is the evolution over time of the population's demographic composition. Usually a higher proportion of prime- or middle-aged people in the population is assumed to stimulate savings as these cohorts prepare for retirement. Higgins (1998) finds substantial demographic effects on the current account balance for a number of countries. However, he also shows that the demographic structure has little effect on net saving in more closed economies. Lindh and Malmberg (1999) present evidence that the proportion of middle-aged people in the population has a positive effect on investment as well as on saving, making the effect on net saving ambiguous. The positive effect on saving and asset accumulation reflects the fact that the middle-aged are preparing for retirement. The reason for the positive effect on investment is not as obvious. Two possible explanations are given. First, the middle-aged tend to transfer wealth from real to financial assets which, given a home bias in investment, would decrease the local cost of capital. Second, the group of middle-aged people is a relatively productive age group, which means a lower effective capital intensity and thus a higher return to capital. ${ }^{3}$

An important determinant of net saving is the fiscal position of the government sector (to the extent that Ricardian equivalence does not hold fully).

\footnotetext{
${ }^{3}$ Lindh and Malmberg (1999) define middle-aged as the age group 50-64 years old, while we use 45-59 years old in the empirical part of the paper. We use this definition because the countries in our study have a lower actual retirement age than 65 .
} 
Thus, high levels of public debt may be associated with lower net foreign assets. ${ }^{4}$ A higher public debt will not be offset by higher private assets if public debt is perceived as net wealth by current generations who will only bear part of the tax burden implied by the higher debt. In this case a higher public debt would depreciate the real exchange rate through the wealth channel discussed above. However, the effect of an increase in the public debt on the real exchange rate is ambiguous. Hakkio (1996) discusses several possible channels through which the fiscal position could influence the exchange rate. One of these channels is the textbook example, see e.g. Ball and Mankiw (1995): In order to increase demand, an increased borrowing and debt by the government will lead to higher prices on non-tradable goods and thus an appreciation of the exchange rate. Thus, whether an increased debt will lead to an appreciation or a depreciation is an empirical question.

In addition to increasing wealth and thus appreciating the exchange rate, higher relative productivity also strengthens the real exchange rate through the Balassa-Samuelson effect. The Balassa-Samuelson effect reflects that if productivity growth is faster in the domestic tradable sector, compared to the foreign tradable sector, this will trigger higher real wage increases which will spill over to the non-tradables sector where it results in relatively higher price increases for non-tradables. This implies an appreciation of the real exchange rate.

Since data on relative productivity often are unreliable, a standard short-cut is to use relative GDP, c.f. Lane and Milesi-Ferretti (2004). However, this shortcut is not unproblematic. Relative GDP will reflect both trend and business cycle differences. What really should matter in the long run is the relative trend output, implying that a more appropriate measure is relative potential GDP.

The interest differential is often argued to be an important determinant of the real exchange rate (e.g. in MacDonald and Marsh 1999). In the short run we know that real interest rates vary over the business cycle and we thus assume (tested and could not reject) that we are able to capture these determinants by the use of our output gap variables.

In order to create a measure of the relative trend output level and the relative cyclical position, we will use an unobserved components model to decompose GDP into trend and cycle.

Based on the discussion above we arrive at the following empirical equations for the $(\log )$ real exchange rates:

$$
\begin{gathered}
e^{s u}=\alpha_{0}+\alpha_{1} q^{s}+\alpha_{2} q^{u}+\alpha_{3} d^{s}+\alpha_{4} d^{u}+\alpha_{5} a c c g^{s}+\alpha_{6} a c c g^{u}+\alpha_{7} y^{n, s}+\alpha_{8} y^{n, u}+\alpha_{9} y^{c, s}+\alpha_{10} y^{c, u}, \\
e^{s e}=\beta_{0}+\beta_{1} q^{s}+\beta_{2} q^{e}+\beta_{3} d^{s}+\beta_{4} d^{e}+\beta_{5} a c c g^{s}+\beta_{6} a c c g^{e}+\beta_{7} y^{n, s}+\beta_{8} y^{n, e}+\beta_{9} y^{c, s}+\beta_{10} y^{c, e},
\end{gathered}
$$

and, ruling out arbitrage possibilities, we have

$$
e^{u e}=e^{s e}-e^{s u}
$$

\footnotetext{
${ }^{4} \mathrm{~A}$ similar decomposition of net foreign assets into demographic and fiscal variables is employed in Masson, Kremers and Horne (1994) and Lane and Milesi-Ferretti (2001).
} 
where $q$ is the terms of trade, $d$ is the share of middle-aged people in the population, and $a c c g$ is the structural government budget debt as a share of GDP, and $y^{n}$ and $y^{c}$ are trend output and output gap, respectively. Superscript $s u$, $s e$ and $u e$ denote SEK/USD, SEK/EUR and USD/EUR and superscript $u, e$ and $s$ denote the US, the Euro area and Sweden respectively.

Since Sweden is a small economy, we will impose a set of restrictions (which we tested and could not reject) that ensures that Swedish variables do not affect the USD/EUR exchange rate. Thus, we assume that Sweden's terms of trade, demographics, structural budget deficit and output will influence the SEK/USD and the SEK/EUR exchange rates by the same amount, leaving the USD/EUR unaffected. Equation (2) then becomes:

$e^{s e}=\beta_{0}+\alpha_{1} q^{s}+\beta_{2} q^{e}+\alpha_{3} d^{s}+\beta_{4} d^{e}+\alpha_{5} a c c g^{s}+\beta_{6} a c c g^{e}+\alpha_{7} y^{n, s}+\beta_{8} y^{n, e}+\alpha_{9} y^{c, s}+\beta_{10} y^{c, e}$.

All business cycle frequency movements in the exchange rates, like the ex ante real interest rate and the cyclical part of the government's budget deficit, are assumed to be captured by the output gap variables in the equations above. The specifications above are flexible and allow for disperse coefficients on e.g. domestic and foreign potential output. The results from estimating a more restricted model is reported below.

Based on findings in the previous empirical literature, which have found a robust positive relation between the terms of trade and the real exchange rate, we expect to find $\alpha_{1}<0$ and $\beta_{2}>0$. To what extent terms of trade shocks in the Euro area and the United States could truly be treated as exogenous is perhaps debatable, but here we follow the current practice in the empirical literature, so that the results will be comparable. Examples of exogenous terms of trade shocks are oil price shocks and shocks to other prices of raw materials determined on the world market. The coefficients on the net saving of the middle-aged, $\alpha_{3}$ and $\beta_{4}$, as well as the coefficients on the structural budget deficits, $\alpha_{5}$ and $\beta_{6}$, could take either sign as discussed above. Regarding trend output, we would expect that $\alpha_{7}<0$ and $\beta_{8}>0$, reflecting an appreciation of the real exchange rate, while the coefficients on the cycles, $\alpha_{9}$ and $\beta_{10}$ could be either positive or negative. A higher output gap should be associated with higher imports and thus with a larger supply of the domestic currency, which would tend to depreciate it. On the other hand, a higher output gap should result in rising domestic prices and higher interest rates, both which would tend to appreciate the currency.

\subsection{The empirical model}

As explained above, we wish to use potential and cyclical output in our exchange rate equation. However, since these variables are not observable they must be estimated. Splitting up a time series in a trend and a cyclical component can be done in several ways. We have chosen a UC-model framework where the parameters are identified through a set of restrictions discussed below and a 
Phillips curve in order to give the cycle an intuitive economic interpretation. ${ }^{5}$ The UC-model is set up in the following way.

Output in each country is assumed to consist of two unobserved components, a permanent non-stationary component and a stationary cyclical component. Dropping country superscripts, the model can be written as:

$$
y_{t}=y_{t}^{n}+y_{t}^{c},
$$

where the permanent component $y^{n}$ is assumed to follow a random walk with drift

$$
\Delta y_{t}^{n}=C+\varepsilon_{t}^{n},
$$

and the cyclical component $y^{c}$ is modelled as a stationary AR-process

$$
y_{t}^{c}=\phi_{1} y_{t-1}^{c}+\phi_{2} y_{t-2}^{c}+\varepsilon_{t}^{c} .
$$

Stationarity implies that the roots of the polynomial equation

$$
1-\phi_{1} L-\phi_{2} L^{2}=0
$$

where $L$ is the lag operator, should lie outside the unit circle. The assumption of an $\operatorname{AR}(2)$ process is not crucial, but it fits the data for all countries.

\subsubsection{Identification}

The unobserved components model above is generally not identified, c.f. Harvey (1989), Jaeger and Parkinson (1994) and Morley, Nelson and Zivot (2002). To obtain an identified model we need to impose some restrictions and add an additional equation to the system.

In order to separate the cycle from the trend and identify the other parameters, we impose that the shocks $\varepsilon_{t}^{i}$ are mutually uncorrelated and normally distributed with variances $\sigma^{2, i}, i=n, c$. In addition to this, we need to add an observable variable to the system that is related to either the cyclical or the permanent component of output, but not to both. An expectations augmented Phillips curve meets this requirement and is modeled as

$$
\Delta p_{t}=\lambda_{0}+\lambda_{1}(L) \Delta p_{t-1}+\lambda_{2}(L) y_{t}^{c}+\lambda_{3}(L) Z_{t}+\varepsilon_{t}^{p}
$$

where $\Delta p_{t}$ is the rate of consumer price inflation and $Z_{t}$ a vector of supply shocks. The shock $\varepsilon_{t}^{p}$ is assumed to be mutually uncorrelated with the other shocks in the model and normally distributed with variance $\sigma^{2, p}$. A more thorough discussion of the Phillips curve is given in Lindblad (1997) and Apel and Jansson (1999).

\footnotetext{
${ }^{5}$ The structural budget deficit will turn out to be a very important variable in the analysis below. It could be argued that the structural deficits should be estimated in the UC framework simultaneously with potential output. However, in order to keep the model simple, we have chosen to use estimates of the structural deficits produced by the OECD.
} 


\subsubsection{The Phillips curve}

We restrict $\lambda_{1}(L)=1$ and temporally aggregate (5) so that we will be working with the quarterly change in the year on year rate of inflation. This takes care of the strong seasonal effects in the data. The overlapping observations are obtained by multiplying through $(5)$ with $\delta(L)=\left(1+L+L^{2}+L^{3}\right)$. We then obtain the following expression for the change in the year on year inflation rate:

$$
\Delta \Delta_{4} p_{t}=\lambda_{0}+\lambda_{2}(L) \delta(L) y_{t}^{c}+\lambda_{3}(L) \delta(L) Z_{t}+\mu_{t}
$$

where $\mu_{t}=\delta(L) \varepsilon_{t}^{p}$. Obviously, the errors will be serially correlated, $E\left(\mu_{t} \mu_{t-s}\right) \neq$ 0 for $0<s<4$. When estimating the model we will therefore allow for a flexible ARMA process for the error term and check the Ljung-Box statistics to arrive at a preferred specification. We use the untransformed cyclical component of output in the estimations, i.e. we estimate the parameters of the polynomial $\lambda_{2}^{*}(L)=\lambda_{2}(L) \delta(L)$.

Since the Phillips curve is used for identification, it is important that the specification is chosen carefully so that no bias is introduced into the parameter estimates for the growth rate. Ignoring supply side changes will in general give rise to misspecification problems. In order to handle this, we have chosen to use import price shocks, $\Delta^{2} p_{M}$, and labor productivity shocks, $\Delta^{2} p r$, as proxies for supply shocks, $Z_{t}$. Thus the extracted potential output is the output level which is consistent with stable inflation in the absence of supply shocks. After temporal aggregation the supply shocks are the quarterly change in the annual rate of import price changes, $\Delta \Delta_{4} p_{M}$, and the quarterly change in the annual rate of labor productivity growth, $\Delta \Delta_{4} p r .{ }^{6}$ We tested several different specifications of our Phillips curves, mainly varying the number of lags of the exogenous variables. The selected specification for Sweden, the US and the Euro area explain 48-65 percent of the variation in the rate of inflation, are parsimoniously specified and the point estimates of parameters are reasonable.

In order to estimate the model, we put it in state space form.

\subsubsection{The transition equations}

The transition equations for each country (still dropping country subscripts) are given by

$$
U_{t}=\Phi U_{t-1}+\varepsilon_{t},
$$

${ }^{6}$ A temporally aggregated supply shock, $\delta(L) \Delta^{2} z_{t}$, can be rewritten as $\left(1+L+L^{2}+L^{3}\right)(1-$ $L)^{2} z_{t}=(1-L)\left(1+L+L^{2}+L^{3}\right)(1-L) z_{t}=(1-L)\left(1-L^{4}\right) z_{t}=\Delta \Delta_{4} z_{t}$. 
where

$$
U_{t}=\left(\begin{array}{c}
\Delta_{4} y_{t}^{n} \\
y_{t}^{c} \\
y_{t-1}^{c} \\
y_{t-2}^{c} \\
y_{t-3}^{c} \\
y_{t-4}^{c} \\
\mu_{t} \\
\mu_{t-1} \\
\mu_{t-2} \\
\mu_{t-3} \\
\mu_{t-4}
\end{array}\right), \Phi=\left(\begin{array}{ccccccccccc}
0 & 0 & 0 & 0 & 0 & 0 & 0 & 0 & 0 & 0 & 0 \\
0 & \phi_{1} & \phi_{2} & 0 & 0 & 0 & 0 & 0 & 0 & 0 & 0 \\
0 & 1 & 0 & 0 & 0 & 0 & 0 & 0 & 0 & 0 & 0 \\
0 & 0 & 1 & 0 & 0 & 0 & 0 & 0 & 0 & 0 & 0 \\
0 & 0 & 0 & 1 & 0 & 0 & 0 & 0 & 0 & 0 & 0 \\
0 & 0 & 0 & 0 & 1 & 0 & 0 & 0 & 0 & 0 & 0 \\
0 & 0 & 0 & 0 & 0 & 0 & \rho_{1} & \rho_{2} & \rho_{3} & \rho_{4} & 0 \\
0 & 0 & 0 & 0 & 0 & 0 & 1 & 0 & 0 & 0 & 0 \\
0 & 0 & 0 & 0 & 0 & 0 & 0 & 1 & 0 & 0 & 0 \\
0 & 0 & 0 & 0 & 0 & 0 & 0 & 0 & 1 & 0 & 0 \\
0 & 0 & 0 & 0 & 0 & 0 & 0 & 0 & 0 & 1 & 0
\end{array}\right), \varepsilon_{t}=\left(\begin{array}{c}
\varepsilon_{t}^{n} \\
\varepsilon_{t}^{c} \\
0 \\
0 \\
0 \\
0 \\
\varepsilon_{t}^{p} \\
0 \\
0 \\
0 \\
0
\end{array}\right),
$$

where $\mu_{t}$ is the shock in equation (6). The transition equations thus are: the random walk part of the trend growth (the drift or constant is included in the measurement equation), the output gap and the ARMA process for the residual in the Phillips curve. ${ }^{7}$ In addition the system includes a set of identities.

\subsubsection{The measurement equations}

The measurement equations for each country are given by

$$
Y_{t}=\Lambda U_{t}+\Psi X_{t},
$$

where (dropping country superscripts) the measurement vector contains changes in output and inflation,

$$
Y_{t}=\left(\begin{array}{c}
\Delta_{4} y_{t} \\
\Delta \Delta_{4} p_{t}
\end{array}\right)
$$

and $\Lambda$ and $\Psi$ are matrices and $X_{t}$ is a vector of exogenous or predetermined variables and a constant, where the exact specifications are given in the tables below.

\subsubsection{The exchange rate equations}

The real exchange rates and the explanatory variables discussed above are all non-stationary, see below. Theory and previous studies indicate that there exists a long-run relationship between the real exchange rate, output, terms of trade, demographic variables, and government budget deficits. A standard way of estimating non-stationary variables is to use an error correction specification. Thus, when estimating the real exchange rates we have chosen the structure in equation (9) below, where the non-stationary variables appear in levels lagged one period. The first difference of all non-stationary variables are also included as explanatory variables in order to capture the short-run dynamics along with

\footnotetext{
${ }^{7} \mathrm{~A}$ moving average specification proved not to be as successful in removing serial correlation as the $\operatorname{AR}(4)$ specification eventually chosen for the error term.
} 
the domestic and the foreign output gap. The bilateral exchange rates given in (1) and (4) are thus modelled as

$$
\Delta E_{t}=\Omega U_{t}^{*}+\Pi\left(\begin{array}{c}
E_{t-1} \\
V_{t-1}
\end{array}\right)+\Gamma \Delta V_{t}+\nu_{t}
$$

where

$$
E_{t}=\left(\begin{array}{c}
e_{t}^{s u} \\
e_{t}^{s e}
\end{array}\right), U_{t}^{*}=\left(\begin{array}{c}
U_{t}^{s} \\
U_{t}^{u} \\
U_{t}^{e}
\end{array}\right), \nu_{t}=\left(\begin{array}{c}
\varepsilon_{t}^{s u} \\
\varepsilon_{t}^{s e}
\end{array}\right)
$$

and $\Omega, \Pi$ and $\Gamma$ are matrices. The matrix $\Omega$ picks out the three countries' cyclical outputs from the $U_{t}^{*}$ vector, $V_{t}$ is a vector containing the rest of the exogenous determinants of the real exchange rates: terms of trade, the share of middle-aged people in the population, structural government budget debt as a share of GDP and trend output. The exchange rate shocks are assumed to be normally distributed and correlated with each other but uncorrelated with the other shocks in the model.

\section{Empirical results}

The empirical models are estimated on a sample of quarterly data ranging from 1973:1 to 2000:4. We have set aside five years of data, 2001:1-2005:4, for a forecasting exercise. The data are presented in Figures 1-11.

In the first step we estimate the output gap, potential output and the inflation rate separately for each country. In the second step we estimate the two bilateral exchange rates simultaneously, using the output gaps and potential output from the first step as regressors. The exchange rate shocks will be correlated with each other and we take advantage of this in using a seemingly unrelated regression estimator. We also impose economically meaningful crossequation restrictions, as explained when discussing equation (4) above, making this a full-fledged system estimation.

When using generated regressors, there is a risk that the estimated standard errors in the second step are biased. However, this is not the case if the generated variables are strongly exogenous for the parameters of interest (c.f. Jansson 1994). In the model above this requirement is fulfilled. Both potential and cyclical output, are strongly exogenous since there is no feedback from the exchange rate to output in our model.

\subsection{Stationarity}

Before estimating the models we must consider the question of stationarity of the variables involved in the analysis.

Identification of the stationary cyclical GDP component requires that all variables in the expectations augmented Phillips-curve are stationary. All explanatory variables of the real exchange rates must also be integrated of the same order. However, the first-differenced variables in the exchange rate equations 
Table 1: Unit root tests

Augmented Dickey-Fuller test. ${ }^{* * *}, * *, *$ denote rejection of a unit root at significance level 1,5 , and 10 percent respectively. Two statistics are reported for the exchange rates, one relating to SEK/USD and one relating to SEK/EUR. Three statistics are reported for the other variables relating to Sweden, Euroland, and the United States. The number of lags used in the tests are also reported.

\begin{tabular}{|l|l|l|}
\hline Variable & Test statistic & Lags \\
\hline$y$ & $-0.04 /-0.87 /-0.01$ & $1 / 1 / 1$ \\
\hline$\Delta_{4} y$ & $-4.40^{* * *} /-3.35^{* * *} /-3.91^{* * *}$ & $3 / 5 / 5$ \\
\hline$\Delta_{4} p$ & $-3.35^{* *} /-4.28^{* * *} /-4.08^{* * *}$ & $7 / 7 / 4$ \\
\hline$\Delta_{4} p_{M}$ & $-9.08^{* * *} /-8.08^{* * *} /-7.48^{* * *}$ & $3 / 3 / 3$ \\
\hline$\Delta \Delta_{4} p r$ & $-8.33^{* * *} /-8.20^{* * *} /-7.32^{* * *}$ & $4 / 3 / 4$ \\
\hline$e$ & $-1.62 /-2.12$ & $3 / 1$ \\
\hline$\Delta e$ & $-6.43^{* * *} /-7.50^{* * *}$ & $1 / 1$ \\
\hline$q$ & $-2.12 /-1.68 /-3.33^{*}$ & $3 / 4 / 5$ \\
\hline$\Delta q$ & $-7.83^{* * *} /-5.64^{* * *} /-7.09^{* * *}$ & $1 / 3 / 1$ \\
\hline$d$ & $-1.38 /-4.07^{* * *} /-0.73$ & $5 / 5 / 5$ \\
\hline$\Delta d$ & $-3.68^{* * *} /-1.85 /-2.27$ & $4 / 4 / 4$ \\
\hline$a c c g$ & $-1.54 /-1.21 /-1.32$ & $5 / 3 / 3$ \\
\hline$g$ & $-2.29 /-0.99 /-0.28$ & $2 / 1 / 1$ \\
\hline$\Delta g$ & $-4.62^{* * *} /-4.43^{* * *} /-4.00^{* * *}$ & $1 / 4 / 2$ \\
\hline
\end{tabular}

should be stationary. As mentioned above, theory states that the real exchange rate is driven by public debt among other variables. Public debt, measured as accumulated structural deficits, accg, seems to be integrated of order one (see Table 1). However, so does the structural deficit, $g$, which is the first difference of the debt level. In addition, the first difference of the deficit seems to be stationary. Juselius (2004) notes "We argue here that the order of integration should be based on statistical rather than economic arguments". Thus, in the empirical analysis below we use the structural deficit, $g^{i}, i=s, u, e$., rather than the public debt level. Table 1 presents the results from the standard augmented Dickey-Fuller test. The lag length is determined by the Akaike information criteria. We interpret the results to be that all variables are integrated of the expected order.

\subsection{Output and inflation}

In Table 2 the results from the estimation of output are reported. The estimated potential growth rates are all of an expected magnitude since they are close to the sample averages. The point estimates of the $\operatorname{AR}(2)$ parameters and thus the cyclical part of output fulfills the criteria for stationarity for all countries. Potential output and the cycles are plotted in Figures 6-8 and 12-14. An inspection of the AR-parameters in the case of Sweden shows that the roots to the corresponding polynomial equation are real. Thus the periodic behavior of 
Table 2: Output equation

Dependent variable: the quarterly change in annual output. The exact specification of the dynamics differ among the models and are available on request. Probability values are reported within parentheses below the estimated coefficients. Serial corr. is a Box-Ljung Q(k) test against serial correlation based on $\mathrm{k}=12$ autocorrelations. Heterosk. is a $\mathrm{Q}(12)$ test of the squared residuals.

\begin{tabular}{|l|l|l|l|}
\hline Variables & Sweden & Euroland & US \\
\hline constant & $\begin{array}{c}1.95 * 10^{-2} \\
(0.00)\end{array}$ & $\begin{array}{l}2.41 * 10^{-2} \\
(0.00)\end{array}$ & $\begin{array}{c}3.08 * 10^{-2} \\
(0.00)\end{array}$ \\
\hline$\phi_{1}$ & $\begin{array}{c}0.64 \\
(0.00)\end{array}$ & $\begin{array}{c}1.15 \\
(0.00)\end{array}$ & $\begin{array}{c}1.21 \\
(0.00)\end{array}$ \\
\hline$\phi_{2}$ & $\begin{array}{c}0.28 \\
(0.00)\end{array}$ & $\begin{array}{c}-0.23 \\
(0.03)\end{array}$ & $\begin{array}{c}-0.30 \\
(0.01)\end{array}$ \\
\hline$\sigma^{c}$ & 0.01 & $6.4 * 10^{-3}$ & $8.3 * 10^{-3}$ \\
\hline$\sigma^{n}$ & $1.1 * 10^{-7}$ & $5.5 * 10^{-4}$ & $2.0 * 10^{-4}$ \\
\hline$R^{2}$ & 0.77 & 0.94 & 0.95 \\
\hline Serial corr. & $(0.281)$ & $(0.716)$ & $(0.261)$ \\
\hline Heterosk. & $(0.681)$ & $(0.702)$ & $(0.242)$ \\
\hline Skewness & -0.52 & 0.93 & -0.29 \\
\hline Kurtosis & 5.15 & 6.76 & 5.23 \\
\hline Jarque-Bera & $(0.000)$ & $(0.000)$ & $(0.000)$ \\
\hline
\end{tabular}

Sweden's cyclical output seems to be due to cyclical shocks rather than to an inherit time series behavior. This was not expected, but the result is robust to alternative specifications of the model. For all countries the estimated variance of the cyclical shock is larger than that of the potential growth shock. This is in line with the results in e.g. Lindblad (1997). In the case of Sweden, it cannot be ruled out that potential output has a deterministic trend, again an unexpected result. Looking at the statistics reported, they suggest that the models are well behaved and explain a surprisingly large fraction of the variation in the output growth rate.

Before estimating the output gaps, we had to specify the empirical Phillips curve. We started out, as discussed above, with a flexible specification and ran a set of OLS regressions to reduce the model with respect to whether or not a variable was significant and whether or not the models behaved well in a statistical manner.

The resulting Phillips curve specification was then augmented with the output gap according to equation (5), and constitutes the second equation in the measurement system.

The estimation results are reported in Table 3. All parameters in the Phillips curve equation have the expected signs and are highly significant. They also proved to be surprisingly stable with respect to changes in the specification. The size of the different parameters seems reasonable, although the output gap parameter is perhaps slightly smaller than expected. The sum of the import price shocks are reasonable, and not far from the import penetration in private 
Table 3: The expectations-augmented Phillips curve

Dependent variable: the quarterly change in the annual rate of inflation. The exact specification of the dynamics differ among the countries and the full results are available on request. Probability values are reported within parentheses below the estimated coefficients. Serial corr. is a Box-Ljung $\mathrm{Q}(\mathrm{k})$ test against serial correlation based on $\mathrm{k}=12$ autocorrelations. Heterosk. is a Q(12) test of the squared residuals.

\begin{tabular}{|l|l|l|l|}
\hline Variables & Sweden & Euroland & US \\
\hline$y_{t}^{c}$ & $\begin{array}{c}0.07 \\
(0.00)\end{array}$ & $\begin{array}{c}0.07 \\
(0.00)\end{array}$ & $\begin{array}{c}0.10 \\
(0.00)\end{array}$ \\
\hline$y_{t-3}^{c}$ & & & \\
\hline$y_{t-4}^{c}$ & $\begin{array}{c}-0.04 \\
(0.09)\end{array}$ & $\begin{array}{c}-0.04 \\
(0.02)\end{array}$ & $\begin{array}{c}-0.03 \\
(0.14)\end{array}$ \\
\hline$\Delta_{4} p_{m, t}$ & $\begin{array}{c}0.07 \\
(0.00)\end{array}$ & $\begin{array}{c}0.07 \\
(0.00)\end{array}$ & $\begin{array}{c}0.11 \\
(0.00)\end{array}$ \\
\hline$\Delta_{4} p_{m, t-3}$ & $\begin{array}{c}0.06 \\
(0.00)\end{array}$ & $\begin{array}{c}0.05 \\
(0.00)\end{array}$ & $\begin{array}{c}0.04 \\
(0.01)\end{array}$ \\
\hline$\Delta_{4} p r_{t-2}$ & $\begin{array}{c}-0.09 \\
(0.01)\end{array}$ & $\begin{array}{c}-0.07 \\
(0.14)\end{array}$ & $\begin{array}{c}3.8 * 10^{-3} \\
(0.92)\end{array}$ \\
\hline$\Delta \Delta_{4} p r_{t-3}$ & -0.07 & -0.04 & \\
\hline$\sigma_{p}$ & $(0.01)$ & $(0.33)$ & $4.1 * 10^{-3}$ \\
\hline$\rho_{1}$ & $5.2 * 10^{-3}$ & $2.5 * 10^{-3}$ & 4.16 \\
\hline$\rho_{2}$ & & & $\begin{array}{c}0.16 \\
(0.10)\end{array}$ \\
\hline$\rho_{3}$ & & & -0.30 \\
& & $0.00)$ \\
\hline$\rho_{4}$ & -0.56 & & 0.22 \\
& 0.48 & 0.66 & -0.41 \\
\hline$R^{2}$ & 0.767 & 0.253 & 0.264 \\
\hline Serial corr. & 0.340 & 0.842 & 0.001 \\
\hline Heterosk. & 0.05 & -0.38 & -0.14 \\
\hline Skewness & 3.07 & 3.46 & 3.44 \\
\hline Kurtosis & $(0.969)$ & $(0.161)$ & $(0.530)$ \\
\hline Jarque-Bera & & & \\
\hline & & & 0.65 \\
\hline
\end{tabular}

consumption in the case of Sweden. Considering that the Euro area and US are more closed economies, it is however a bit surprising that the import price effects on Euro area and US inflation are of the same magnitude as in Sweden. Regarding productivity, our point estimates indicate a limited pass-through to inflation in the short run, which should be expected. The statistics reported suggest that the three models are well behaved and explain a large fraction of the variation in the change in inflation rate changes.

The Phillips curve is naturally of special interest for stabilization policy. The finding of an effect from both contemporary and the lagged output gap suggests that there might be a limit to the speed with which the gap can be closed without causing a change in inflation (c.f. Layard, Nickell and Jackman 1991). An implication of a speed limit is that inflation can increase in a situation where 
the output gap is negative if the gap is closing fast enough.

\subsection{Real exchange rates}

The restrictions implying that Swedish variables do not affect the USD/EUR exchange rate are imposed by setting the adjustment parameters equal and also equalizing the parameters relating to Swedish variables when estimating the SEK/USD and SEK/EUR exchange rates. We have tested these restrictions and they where not rejected.

Below we will discuss and report the results from estimating the exchage rate system with respect to two different sets of restrictions. Model 1 is flexible in the sence that there are no restictions on the parameters beside the restiction that Swedish variables should not affect the USD/EUR exchange rate. In model 2 we use relative terms of trade and changes in relative terms of trade instead of separately estimating the effect from each of these variables for the US and the Euro area. Thus we have imposed four additional restrictions in model 2. In both models we have used four devaluation dummies. ${ }^{89}$

The cointegrating relations presented below have all been derived from the variables (with associated estimated coefficients) that appear in levels in Table 4. The cointegrating relations derived for Model 1 are

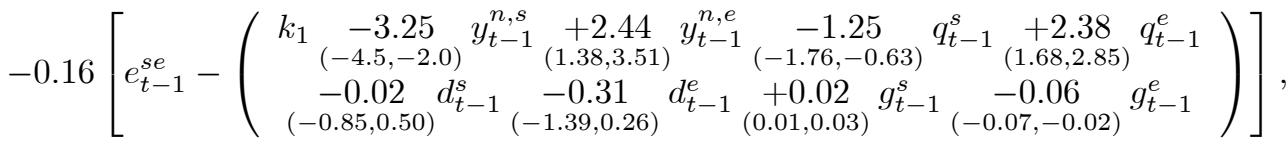

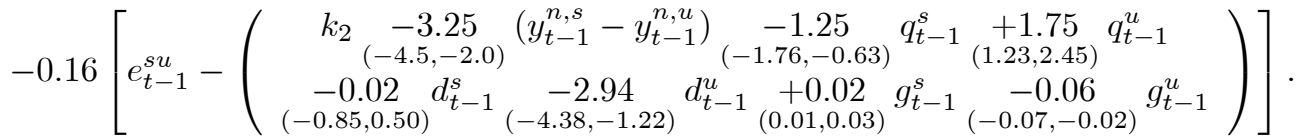

where the $k_{i}$ are unknown constants. ${ }^{10}$ Bootstrapped 90 percent t-confidence intervals (using 5000 replications) are reported within parentheses below the coefficients, which have been computed from the estimated coefficients in Table 4. We also bootstrapped percentile confidence intervals. These were very similar to the t-confidence intervals, indicating no need for more elaborate bootsprapping methods.

The corresponding cointegrating relations for Model 2 are

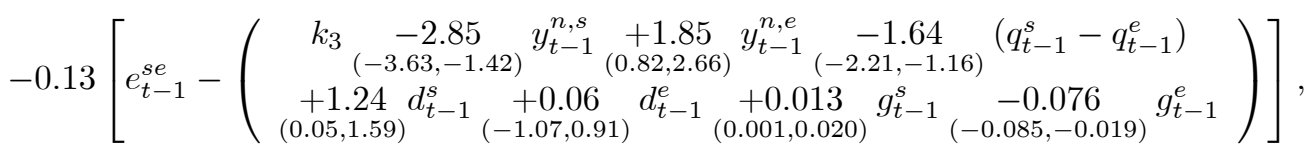

\footnotetext{
${ }^{8}$ To remove spikes in the residuals due to devaluations of the Krona we have used impulse dummies for the following quarters: 1977:4, 1981:4, 1982:4, and 1993:1.

${ }^{9}$ Different monetary regimes could motivate different models of the real exchange rate. Larsson (2002) tests this and finds some support for a regime-dependent behavior in the SEK/DEM real exchange rate.

${ }^{10}$ The constants are unknown since we do not know from the estimated equations what part of the estimated constant pertains to the cointegrating relation.
} 
Table 4: Exchange rate equation

Dependent variable: the percentage change in the real exchange rate. Probability values are reported within parentheses below the estimated coefficients. The complete model results are available on request. We have used four devaluation dummies, 1977:4, 1981:4, 1982:4 and 1993:1 (the SEK has floated freely since 19 November 1992). Serial corr. is a Box-Ljung Q(k) test against serial correlation based on $\mathrm{k}=12$ autocorrelations. Heterosk. is a $\mathrm{Q}(12)$ test of the squared residuals.

\begin{tabular}{|c|c|c|c|c|}
\hline & \multicolumn{2}{|c|}{$\Delta \log (\mathrm{SEK} / \mathrm{USD})$} & \multicolumn{2}{|c|}{$\Delta \log ($ SEK $/$ EUR $)$} \\
\hline Variables & Model 1 & Model 2 & Model 1 & Model 2 \\
\hline$y^{c, s}$ & $\begin{array}{l}0.06 \\
(0.58)\end{array}$ & $\begin{array}{c}-0.06 \\
(0.60)\end{array}$ & $\begin{array}{l}0.06 \\
(0.58)\end{array}$ & $\begin{array}{c}-0.06 \\
(0.60)\end{array}$ \\
\hline$y^{c, *}, *=u, e$ & $\begin{array}{l}-0.25 \\
(0.19)\end{array}$ & $\begin{array}{l}-0.28 \\
(0.12)\end{array}$ & $\begin{array}{l}-0.14 \\
(0.37)\end{array}$ & $\begin{array}{c}-0.03 \\
(0.86)\end{array}$ \\
\hline$e_{t-1}$ & $\begin{array}{l}-0.16 \\
(0.00)\end{array}$ & $\begin{array}{l}-0.13 \\
(0.00)\end{array}$ & $\begin{array}{c}-0.16 \\
(0.00)\end{array}$ & $\begin{array}{c}-0.13 \\
(0.00)\end{array}$ \\
\hline$y_{t-1}^{n, s}$ & & & $\begin{array}{c}-0.52 \\
(0.00)\end{array}$ & $\begin{array}{c}-0.36 \\
(0.00)\end{array}$ \\
\hline$y_{t-1}^{n, *}, *=u, e$ & & & $\begin{array}{l}0.39 \\
(0.01)\end{array}$ & $\begin{array}{l}0.24 \\
(0.02)\end{array}$ \\
\hline$\left(y^{n, s}-y^{n, *}\right)_{t-1}$ & $\begin{array}{c}-0.52 \\
(0.00)\end{array}$ & $\begin{array}{c}-0.36 \\
(0.00)\end{array}$ & & \\
\hline$q_{t-1}^{s}$ & $\begin{array}{c}-0.20 \\
(0.02)\end{array}$ & & $\begin{array}{c}-0.20 \\
(0.02)\end{array}$ & \\
\hline$q_{t-1}^{*}, *=u, e$ & $\begin{array}{l}0.28 \\
(0.01) \\
\end{array}$ & & $\begin{array}{l}0.38 \\
(0.00) \\
\end{array}$ & \\
\hline$\left(q^{s}-q^{*}\right)_{t-1}$ & & $\begin{array}{l}-0.21 \\
(0.01)\end{array}$ & & $\begin{array}{l}-0.21 \\
(0.01)\end{array}$ \\
\hline$d_{t-1}^{s}$ & $\begin{array}{c}-2.8 * 10^{-3} \\
(0.97)\end{array}$ & $\begin{array}{c}0.16 \\
(0.04)\end{array}$ & $\begin{array}{c}-2.8 * 10^{-3} \\
(0.97)\end{array}$ & $\begin{array}{l}0.16 \\
(0.04)\end{array}$ \\
\hline$d_{t-1}^{*}, *=u, e$ & $\begin{array}{c}-0.47 \\
(0.02)\end{array}$ & $\begin{array}{c}-0.46 \\
(0.00)\end{array}$ & $\begin{array}{l}-0.05 \\
(0.64)\end{array}$ & $\begin{array}{l}0.01 \\
(0.94)\end{array}$ \\
\hline$g_{t-1}^{S}$ & $\begin{array}{c}3.3 * 10^{-3} \\
(0.01)\end{array}$ & $\begin{array}{c}1.7 * 10^{-3} \\
(0.09)\end{array}$ & $\begin{array}{c}3.3 * 10^{-3} \\
(0.01)\end{array}$ & $\begin{array}{c}1.7 * 10^{-3} \\
(0.09)\end{array}$ \\
\hline$g_{t-1}^{*}, *=u, e$ & $\begin{array}{l}-0.01 \\
(0.00)\end{array}$ & $\begin{array}{l}-0.01 \\
(0.00)\end{array}$ & $\begin{array}{l}-0.01 \\
(0.00)\end{array}$ & $\begin{array}{l}-0.01 \\
(0.00)\end{array}$ \\
\hline$\Delta q_{t}^{s}$ & $\begin{array}{c}-0.76 \\
(0.00)\end{array}$ & & $\begin{array}{c}-0.76 \\
(0.00)\end{array}$ & \\
\hline$\Delta q_{t}^{*}, *=u, e$ & $\begin{array}{l}0.94 \\
(0.00) \\
\end{array}$ & & $\begin{array}{l}0.95 \\
(0.00) \\
\end{array}$ & \\
\hline$\left(\Delta q^{s}-\Delta q^{*}\right)_{t}$ & & $\begin{array}{c}-0.86 \\
(0.00)\end{array}$ & & $\begin{array}{c}-0.86 \\
(0.00)\end{array}$ \\
\hline$S E$ & 0.03 & 0.03 & 0.02 & 0.02 \\
\hline $\bar{R}^{2}$ & 0.57 & 0.57 & 0.67 & 0.64 \\
\hline Serial corr. & $(0.409)$ & $(0.439)$ & $(0.467)$ & $(0.680)$ \\
\hline Heterosk. & $(0.470)$ & $(0.750)$ & $(0.000)$ & $(0.000)$ \\
\hline Skewness & 0.40 & 0.57 & 0.27 & 0.30 \\
\hline Kurtosis & 3.54 & 4.02 & 3.32 & 3.20 \\
\hline Jarque-Bera & $(0.113)$ & $(0.004)$ & $(0.395)$ & $(0.391)$ \\
\hline Dummies & Yes & Yes & Yes & Yes \\
\hline
\end{tabular}




$$
-0.13\left[e_{t-1}^{s u}-\left(\begin{array}{c}
k_{4} \underset{(-3.63,-1.42)}{-2.85}\left(y_{t-1}^{n, s}-y_{t-1}^{n, u}\right) \underset{(-2.21,-1.16)}{-1.64}\left(q_{t-1}^{s}-q_{t-1}^{u}\right) \\
+1.24 d_{t-1}^{s} \underset{(-4.32,-1.19)}{-3.64} d_{t-1}^{u} \underset{(0.001,0.020)}{+0.013} g_{t-1}^{s} \underset{(-0.12,-0.03)}{-0.10} g_{t-1}^{u}
\end{array}\right)\right] .
$$

Using these equations we can calculate the corresponding cointegrating relations for the USD/EUR real exchange rate as

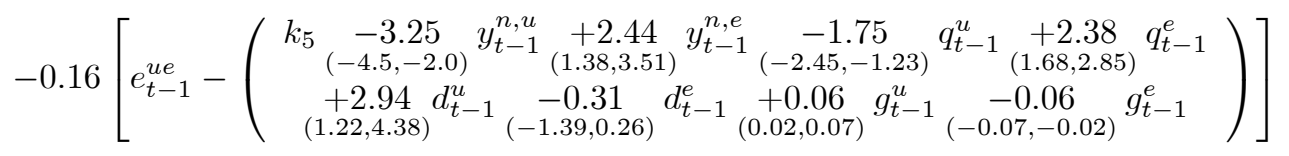

in the case of model 1 , and for model 2 we get

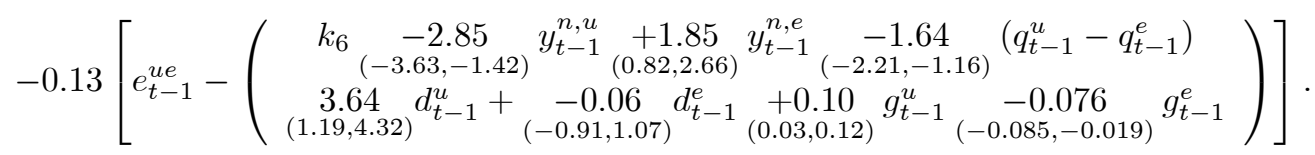

The results presented in Table 4 and above are well in line with what we expected from our introductory theoretical discussion.

One objective of this paper is to make use of estimated potential output instead of approximating it with GDP, which has so far been the standard route in the literature. Thus in order to find out if it is worthwhile to filter output, we replaced our potential output estimates in the regressions above with observed GDP. This resulted in a less accurate model (not shown). Estimates of potential and cyclical output plugged into our exchange rate system consequently resulted in a superior empirical model in terms of adjusted $R^{2}$.

Relative potential output and potential output always enter significantly and with expected signs. The long-run coefficients given in the error correction equations above indicate that an increase in relative potential output strengthens the exchange rate substantially.

According to previous studies an increase in terms of trade should cause an appreciation of the exchange rate. Relative terms of trade, terms of trade and the change in terms of trade always enter highly significantly and with expected signs. The point estimates show that terms of trade is potentially of substantial importance in explaining the evolution of the real exchange rates, which is in line with previous results (c.f. Lane and Milesi-Ferretti 2004).

Theory suggests that the net foreign assets are important. As discussed above, exogenous determinants of the net foreign asset position are the demographic structure and government fiscal position. Regarding the demographic variables the results are mixed. However when the parameters are more precisely estimated, as is always the case for the US and Swedish demographic variables in Model 2, the point estimates suggest that a relative increase in the fraction of middle-aged people will have a depreciating effect on the exchange rate. The insignificance of the Euro area demographic variables could be due to a low degree of openness, as suggested by Higgins (1998), or as a result of increased savings being offset by a positive effect on investment, as suggested 
in Lindh and Malmberg (1999). The point estimates could also indicate that in order to accumulate funds ahead of retirement, the real exchange rate has to depreciate. The structural budget situation is clearly of importance. Our point estimates are highly significant and indicate that an increased structural deficit will have a substantial depreciating effect. The estimates indicate that the effect is larger for the Euro area and the US than for Sweden. An increase of the structural deficit by one per cent of GDP in the US could depreciate the USD/EUR exchange rate by as much as 8 per cent. The structural deficit is obviously a prime candidate for partly explaining the recent USD/EUR development.

Regarding short run dynamics, changes in the terms of trade are important and estimated quite precisely. However, the opposite applies to the business cycle effect on the real exchange rate dynamics, the cyclical part of output enters significantly only in one case. ${ }^{11}$

Looking at the statistics reported, they suggest that the models are well behaved and explain a large fraction of the variation in the real exchange rate changes. The values of the adjusted $R^{2 \prime} s$ range from 0.57 to 0.64 .

The long-run relationships are shown together with the actual real bilateral exchange rates in Figures 15-17. ${ }^{12}$ The Swedish krona has followed a depreciating trend over the whole sample period 1973-2000. The nominal exchange rate was fixed (but devalued several times) up until November 19, 1992, when the Krona was allowed to float. The fundamentals of the model are able to explain the long-run movements in the SEK/USD and SEK/EUR exchange rates. Especially noteworthy is the depreciation of the SEK/EUR given by our models which occurs well ahead of the floating of the krona in late 1992. The implied USD/EUR long-run relations shown in Figure 17 also provide a good fundamental explanation of the actual USD/EUR exchange rate. The major movements in our model precede major movements in the actual exchange rate.

In Figures 18-20 we show the complete model (in levels form) that allows for short run dynamics as well as the error correction term. The devaluation effects in 1977:4, 1981:4 and 1982:4, as well as the large depreciation in 1993:1, have been captured by including devaluation dummies to handle the resulting spikes in the time series. Compared to the long-run relations we get a somewhat better fit, although the major movements are already captured in Figures 1517. Of course, with dummy variables included the level shifts will occur in those quarters and not precede the devaluations as was the case before.

We also show the models' forecasts up to the 4th quarter of 2005. The first part of the forecast 2001-2003 is a pseudo out of sample exercise since we use actual values of the explanatory variables up to the last quarter of 2003. Compared with the actual exchange rate movements 2001-2003 our models do very well in capturing the rise and fall of the dollar. The structural budget deficit of the U.S. is the central variable responsible for the success of the forecast performance during this period. The models also captures the slight depreciation

\footnotetext{
${ }^{11}$ We tried to include several measures of the real interest differential, but this did not improve the results.

${ }^{12}$ The constants, $k_{i}$, have been determined such that the sample averages of the error correction terms are equal to zero.
} 
of the Krona vis-a-vis the Euro. During the later forecast period 2004-2005 the growth rates are assumed to be at their potential and the terms of trade are assumed to be unchanged. Demographic projections from Statistics Sweden and OECD, and projections of cyclically adjusted fiscal balances from the OECD have been used.

\section{Conclusion}

The evolution of a real exchange rate is often hard to understand, especially the short-run movements. Not seldom has it been claimed that a real exchange rate is best approximated by a random walk, that is that the best guess for tomorrow is the going rate today. Theoretically it has been shown that a real exchange rate is determined, at least in the longer run, by a set of factors such as e.g. terms of trade, output or productivity differentials and the net foreign asset position.

The most common approach when analyzing and estimating real exchange rates is to study a bilateral exchange rate or comparing one currency to a weighted basket of other currencies and adjusting for relative price levels. In the case of Sweden the usual approach has been to compare the Swedish Krona with a trade-weighted basket or the Euro, and multiplying the nominal exchange rate with the relative consumer price level.

The contribution of this paper is to estimate a small system of different real exchange rates in order to simultaneously being able to analyze movements in the real exchange rate between the Krona, the Euro and the Dollar, the three most important real exchange rates for Swedish exports.

Our empirical model is based on the theoretical results from the new open macroeconomics literature. In our specification the real exchange rate is determined by terms of trade, relative potential output and a set of exogenous variables that are assumed to determine the net foreign asset position. Potential output in Sweden, the Euro area and the US is successfully estimated separately in an unobserved components framework, including an expectations augmented Phillips curve.

We believe that our results are promising. We are able to explain a large fraction of the variation in the change of the real exchange rates. Our point estimates are in line with theory and highly significant. This is also true for the estimated output equation and the Phillips curve.

Starting with potential output, our estimates indicate that potential growth is highest in the US, followed by the Euro area. Our Phillips curve estimates show that inflation is more sensitive to the output gap in the US than in Sweden and the Euro area. A somewhat unexpected result is that inflation is at least as sensitive to import price shocks in the US and the Euro area as in Sweden, despite the fact that the Swedish economy is more open. Regarding the real exchange rates, an increase in relative potential output strengthens the currency. The Krona and the Dollar benefit more from this effect than the Euro. Terms of trade are important, both in the long-run and in explaining short-run 
movements. An increase in the export prices relative to import prices strengthens the currency of the exporting country. When estimating the effect without restrictions it seems as if the Euro area benefits the most from an increase in the export prices. We have chosen to use the relative demographic situation and relative structural fiscal position of the government as an approximation to net foreign assets. When statistically significant, an increase in the relative middle-age cohorts is found to weaken the exchange rate. The structural budget situation is of great importance and an increase in the deficit has a depreciating effect. The point estimates indicate that the effect is larger for the US and the Euro area than for Sweden. An increase in the US deficit by one per cent of GDP could depreciate the USD/EUR by as much as 8 per cent, and is thus an important candidate explaining the large movements lately.

Finally, we believe that the approach in this paper could be of use when analyzing the proper value of a real exchange rate. This is an important task, e.g. for the set of countries that joined the European Union during 2004 and plan to adopt the Euro later on. When determining the central rate within the European Exchange Rate Mechanism, ERM2, and later on the conversion rate, it is important that the decided nominal rate does not induce an inflation shock in order to restore an economically motivated real exchange rate. 


\section{Data appendix}

- $a c c g=$ accumulated structural budget deficits $g$, as a percent of potential GDP (as computed by the OECD).

- $d$ = Middle-age ratio, computed as the sum of 45-59 years old relative to the total population.

- $e=$ Real exchange rate computed as the (log) of the product of the nominal exchange rate and relative consumer prices. In the case of SEK/USD the real exchange rate is $\log \left(S E K / U S D \cdot P^{u} / P\right)$

- $g=$ structural government deficit (as percent of potential GDP as computed by the OECD).

- $P=$ Consumer price index.

- $P_{X}=$ Export deflator.

- $P_{M}=$ Import deflator.

- $p r=\log$ of labor productivity (GDP per hours worked).

- $q=\log \left(P_{X} / P_{M}\right)$, the terms of trade, computed as export deflator over import deflator.

- $y=\log$ of real gross domestic product (s.a.). 


\section{References}

[1] Alexius, A. (2001). Sources of real exchange rate fluctuations in the Nordic countries. Scandinavian Journal of Economics 103.

[2] Alexius, A. and J. Nilsson (2000). Real exchange rates and fundamentals: Evidence from 15 OECD countries. Open Economies Review 11, 383-397.

[3] Apel, M. and P. Jansson (1999). System estimates of potential output and the NAIRU. Empirical Economics 24(3).

[4] Ball, L. and N.G. Mankiw (1995). What do budget deficits do? in Budget deficits and debt: issues and options, a symposium sponsored by The Federal Reserve Bank of Kansas City, Jackson Hole, Wyoming.

[5] Bergvall, A. (2002). What determines real exchange rates? The Nordic countries. Working Paper 2002:15, Uppsala University.

[6] Davidson, R. and J.G. MacKinnon (1993). Estimation and inference in econometrics. Oxford University Press.

[7] Dungey, M. (2002). Identifying terms of trade effects in real exchange rate movements: evidence from Asia. Paper presented at the 24th International Conference on Asian Economic Studies, Beijing University, May 26-29, 2002. Mimeo, Australian National University.

[8] Ghironi, F. (2000). Towards new open economy macroeconometrics. Mimeo, Department of Economics, Boston College.

[9] Greene, W.H. (1993). Econometric Analysis, 2nd ed. Prentice-Hall, Englewood Cliffs, NJ.

[10] Hakkio, C.S. (1996). The effect of budget deficit reduction on the exchange rate. Economic Review, Federal Reserve Bank of Kansas City.

[11] Harvey, A.C. (1989). Forecasting, structural time series models and the Kalman filter, Cambridge University Press.

[12] Higgins, M. (1998). Demography, national savings, and international capital flows. International Economic Review 39(2).

[13] Hjelm, G. (2001). Total Factor Productivity and the Real Exchange Rate in a Small Open Economy: The Relative Importance of Permanent and Transitory Shocks. Working Paper No. 2001:23, Lund University.

[14] Jaeger, A. and M. Parkinson (1994). Some evidence on hysteresis in unemployment rates. European Economic Review 38.

[15] Jansson, P. (1994). Essays on Empirical Macroeconomics, Economic Studies 20, Uppsala University. 
[16] Juselius, K. (2004). The Cointegrated VAR Model: Econometric Methodology and Macroeconomic Applications. Lecture Notes, Univerisity of Copenhagen.

[17] Lane, P.R. (2001). The new open macroeconomics: a survey. Journal of International Economics 54, 235-266.

[18] Lane, P.R. and G.M. Milesi-Ferretti (2001). Long-Term Capital Movements. NBER Macroeconomics Annual 2001.

[19] Lane, P.R. and G.M. Milesi-Ferretti (2004). The transfer problem revisited: net foreign assets and real exchange rates. The Review of Economics and Statistics 84(4), 841-857.

[20] Larsson, A. (2002). The Swedish real exchange rate under different currency regimes. Working Paper No. 180, FIEF.

[21] Laubach, T. (2001). Measuring the NAIRU: evidence fron seven economies. The Review of Economics and Statistics 83(2), 218-231.

[22] Layard, R., S. Nickel and R. Jackman (1991). Unemployment: macroeconomic performance and the labor market. Oxford University Press, Oxford

[23] Lindblad, H. (1997). Persistence in Swedish unemployment rates. Working Paper 1997:3, Dept. of Economics, Univerity of Stockholm.

[24] Lindh, T. and B. Malmberg (1999). Age structure and the current account a changing relation? Working Paper 1999:21, Dept. of Economics, Uppsala University.

[25] MacDonald, R. (2000). Concepts to calculate equilibrium exchange rates: an overview. Discussion paper 3/00, Deutsche Bundesbank.

[26] MacDonald, R. and I. Marsh (1999). Currency spillovers and tri-polarity: a simultaneous model of the U.S. dollar, German mark and Japanese yen. Journal of International Money and Finance 23, 99-111.

[27] Masson, P.R., J. Kremers and J. Horne (1994). Net foreign assets and international adjustment: the United States, Japan, and Germany. Journal of International Money and Finance, 13(1), 27-40.

[28] Morley, J.C., C.R. Nelson and E. Zivot (2003). Why are Beveridge-Nelson and unobserved-component decompositions of GDp so different? Review of Economics and Statistics 85(2), 235-243.

[29] Nilsson, K. (2002). Do fundamentals explain the behaviour of the real effective exchange rate? Working paper no. 78, National Institute of Economic Research, Sweden.

[30] Obstfeld, M. and K. Rogoff (2004). The Unsustainable US Current Account Position Revisited. NBER Working paper No. 10869. 
Figure 1. Annual real GDP growth

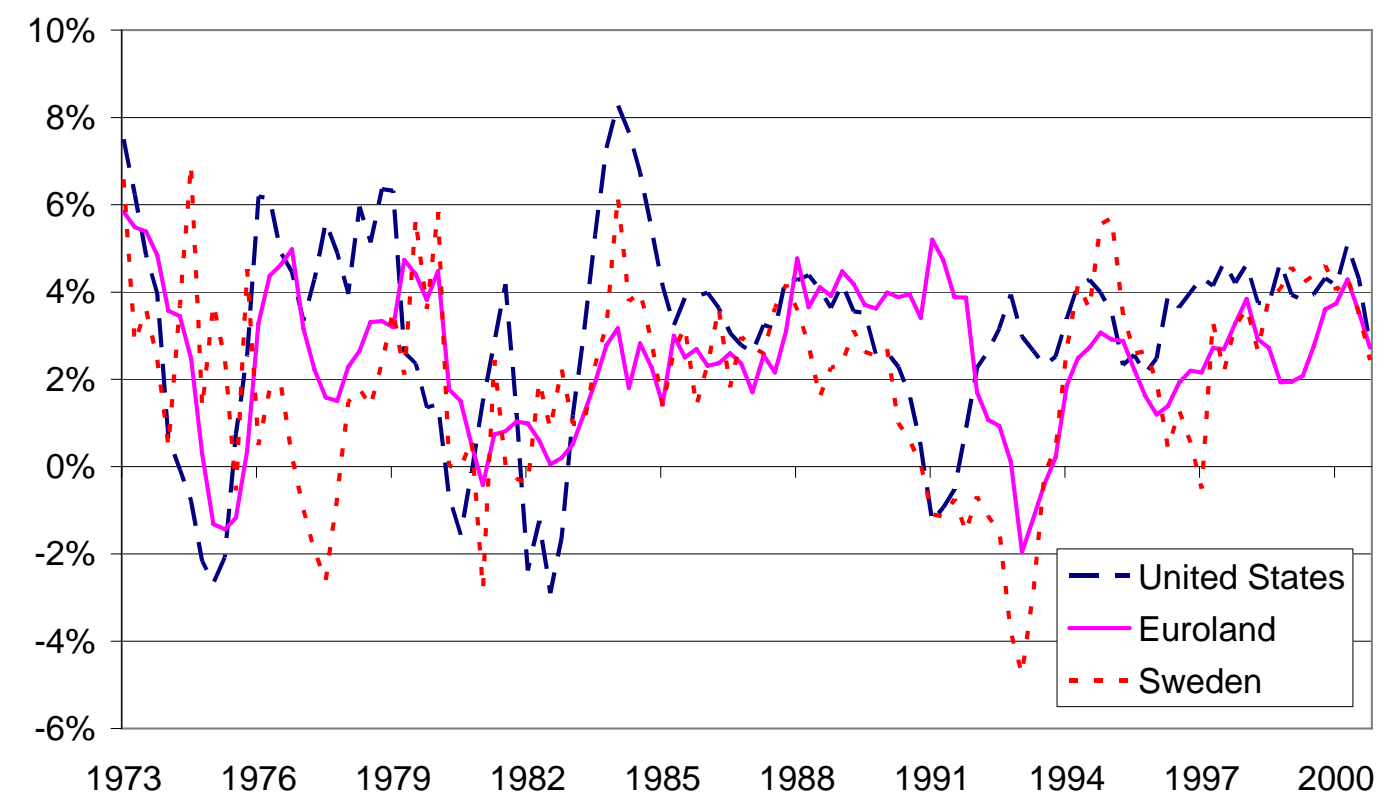

Figure 2. Quarterly change in annual inflation

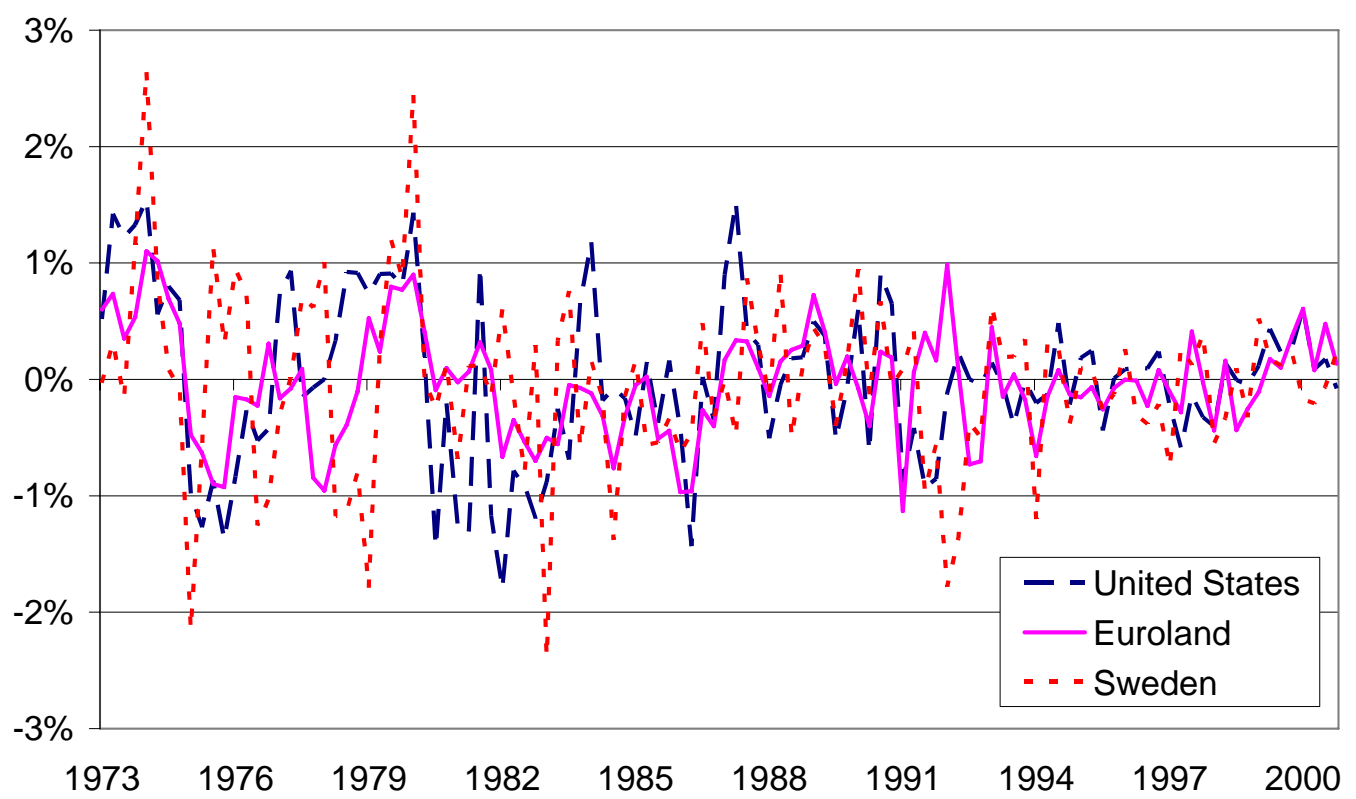


Figure 3. Import price shocks

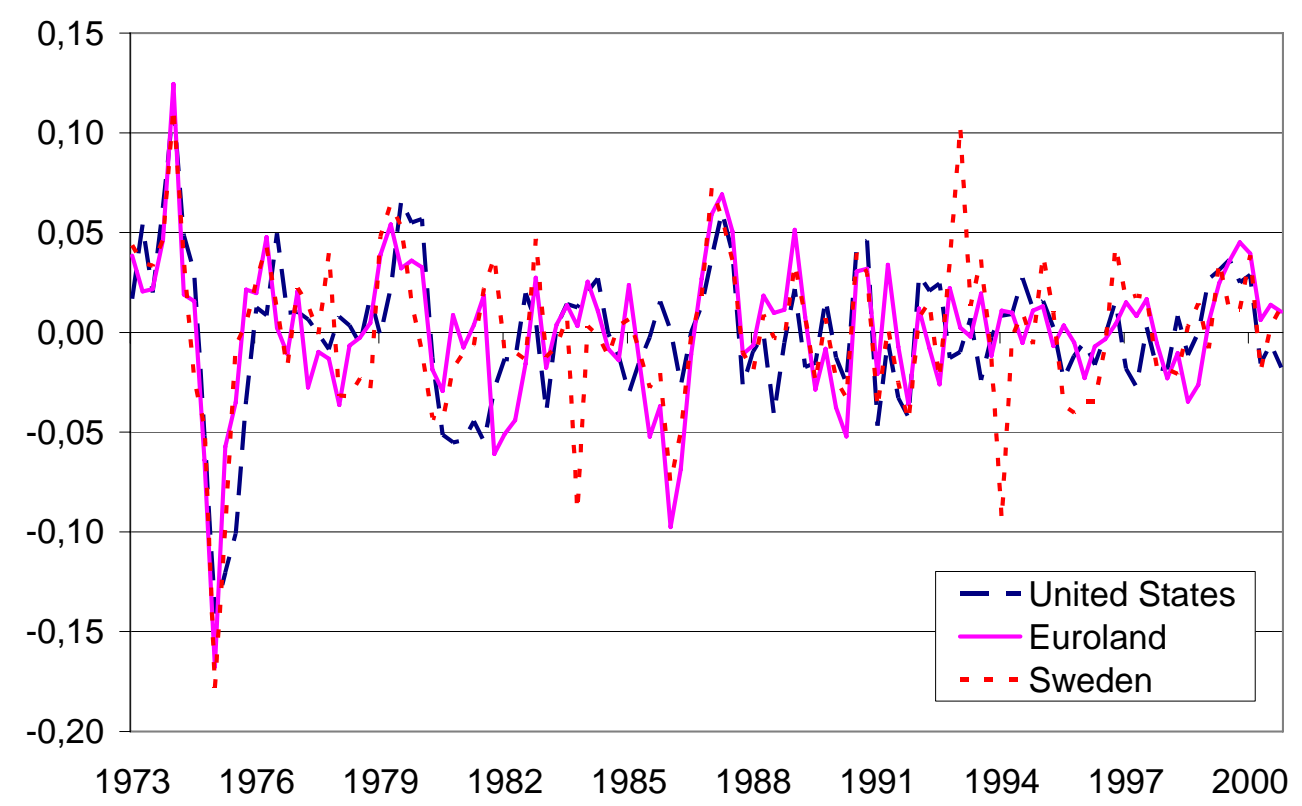

Figure 4. Productivity shocks

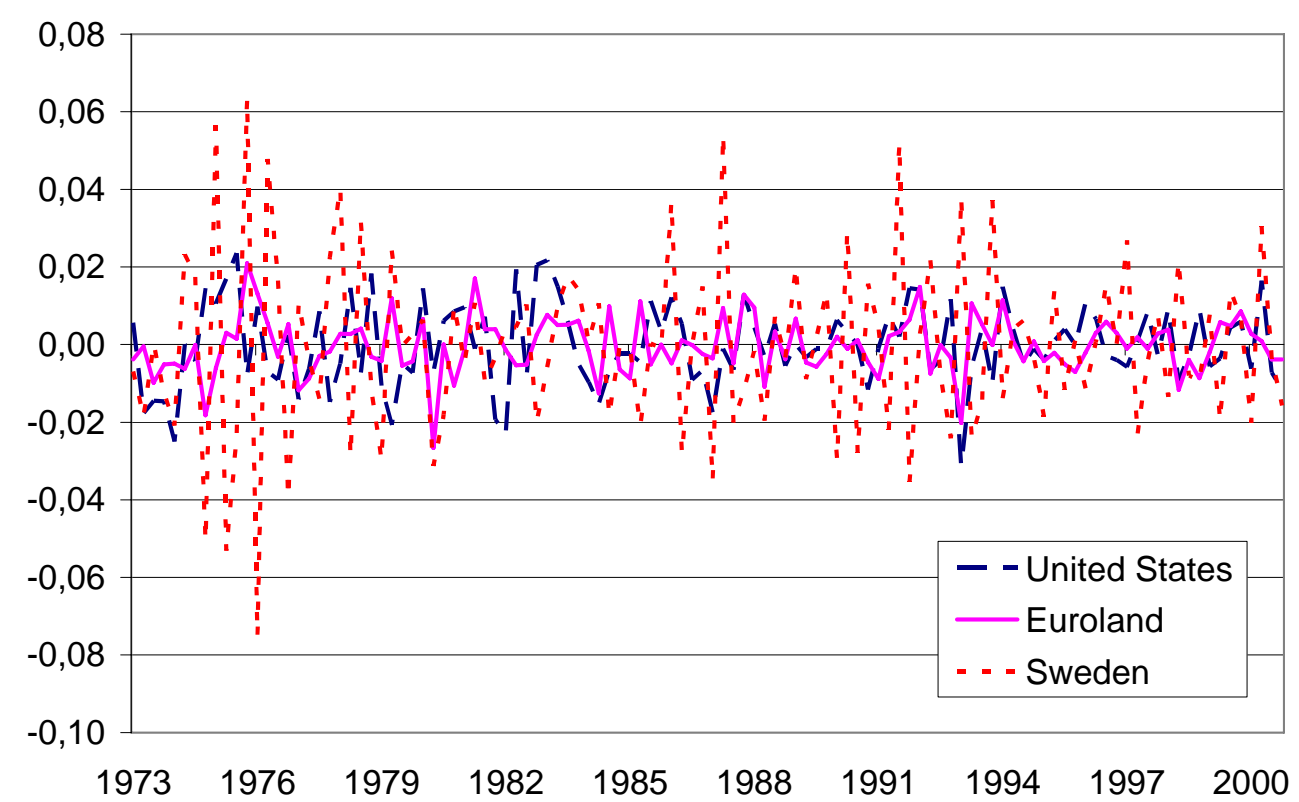


Figure 5. Quarterly change in real exchange rate

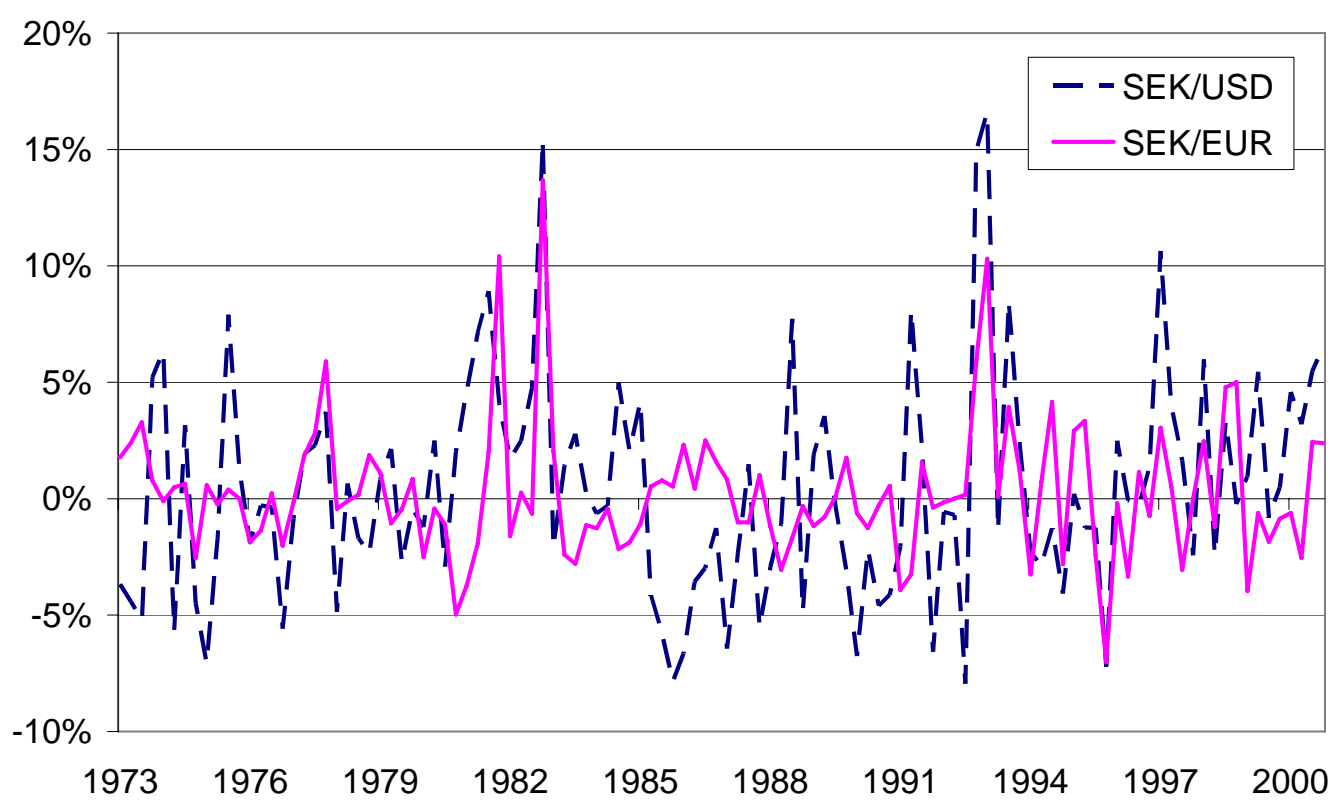

Figure 6. Actual and potential U.S. log GDP

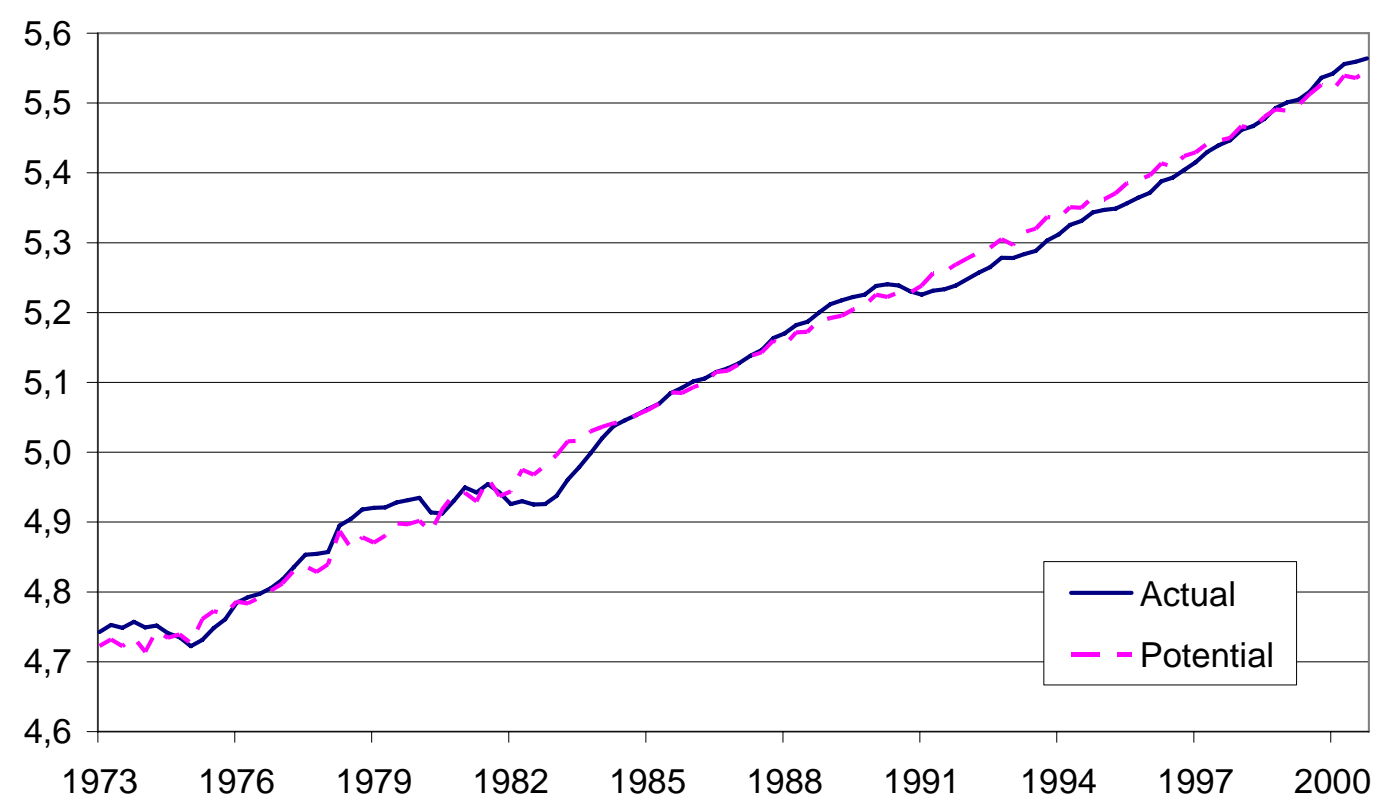


Figure 7. Actual and potential Euroland log GDP

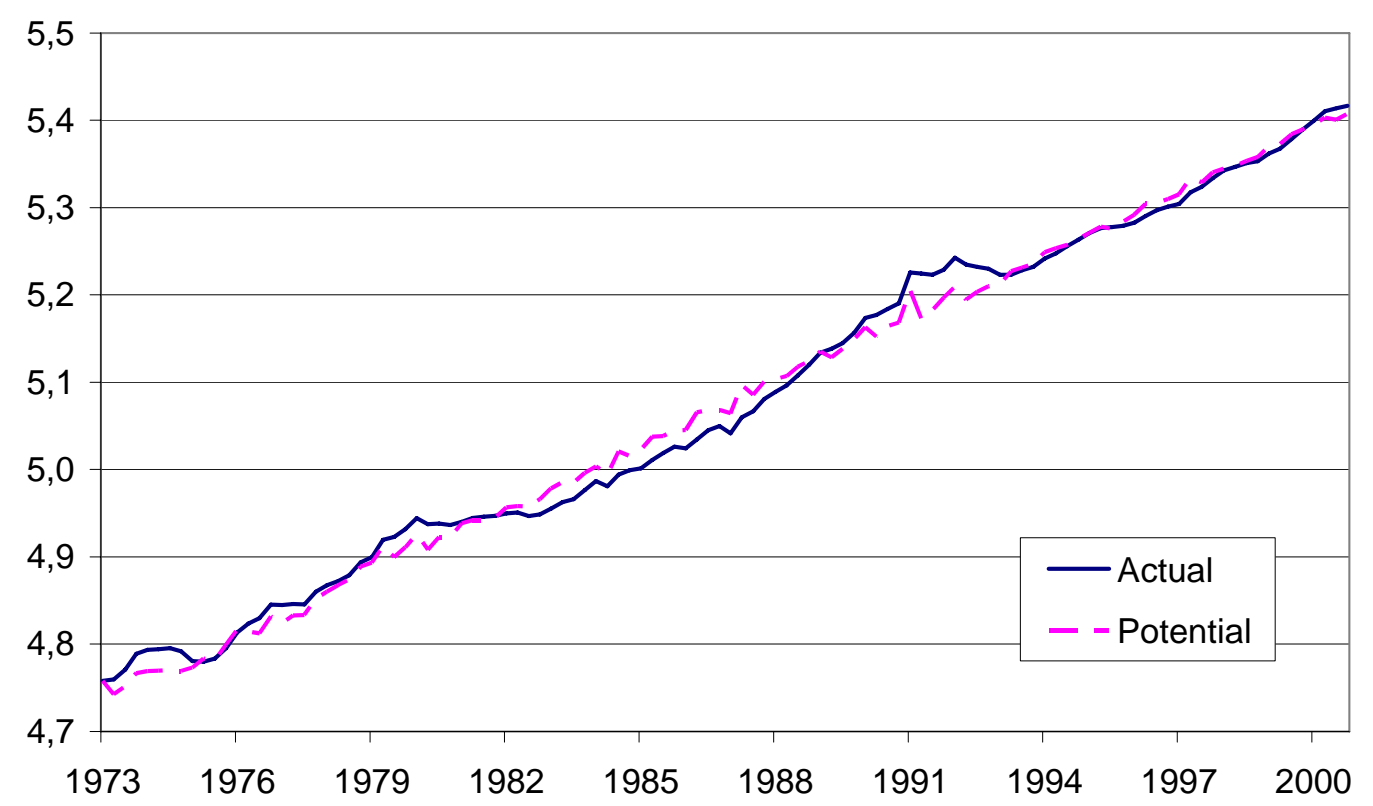

Figure 8. Actual and potential Swedish log GDP

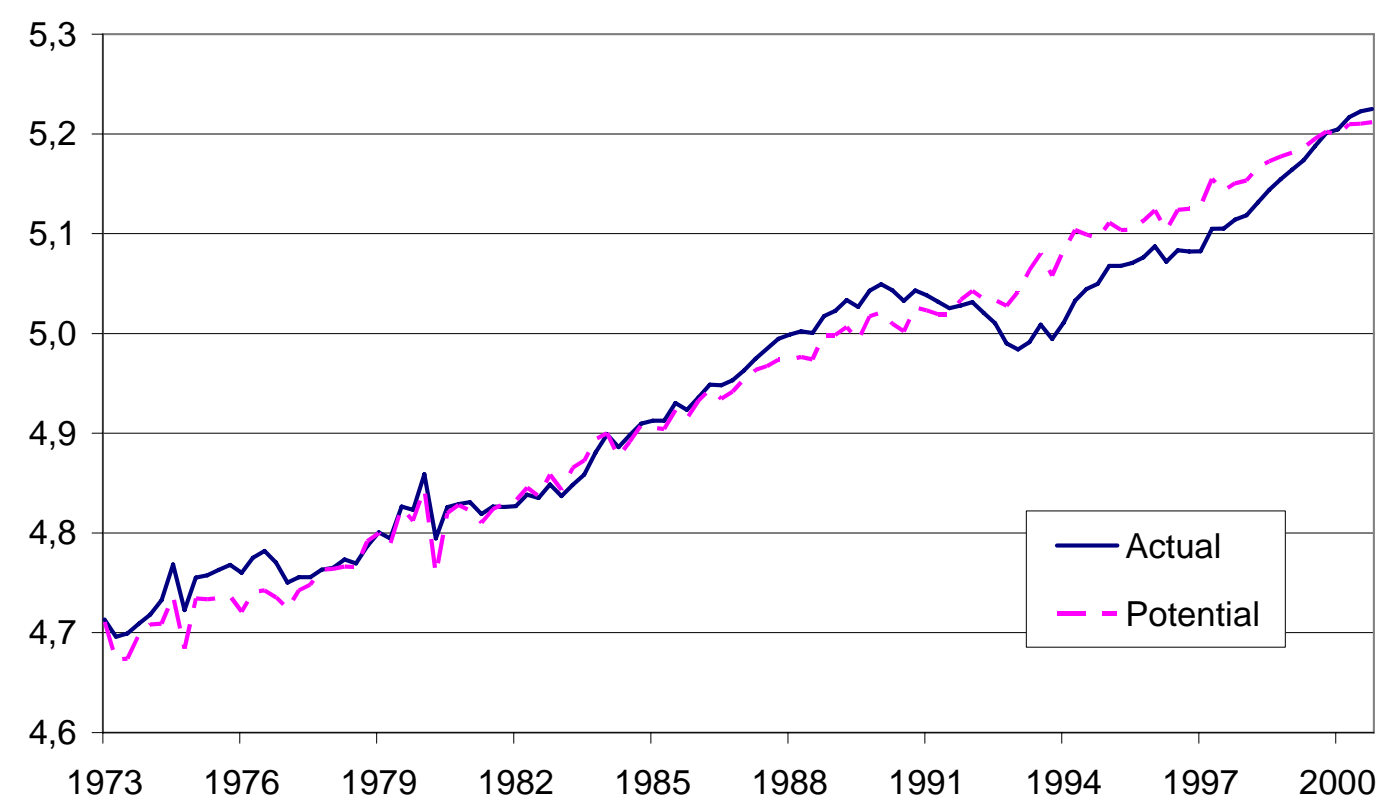


Figure 9. Log terms of trade

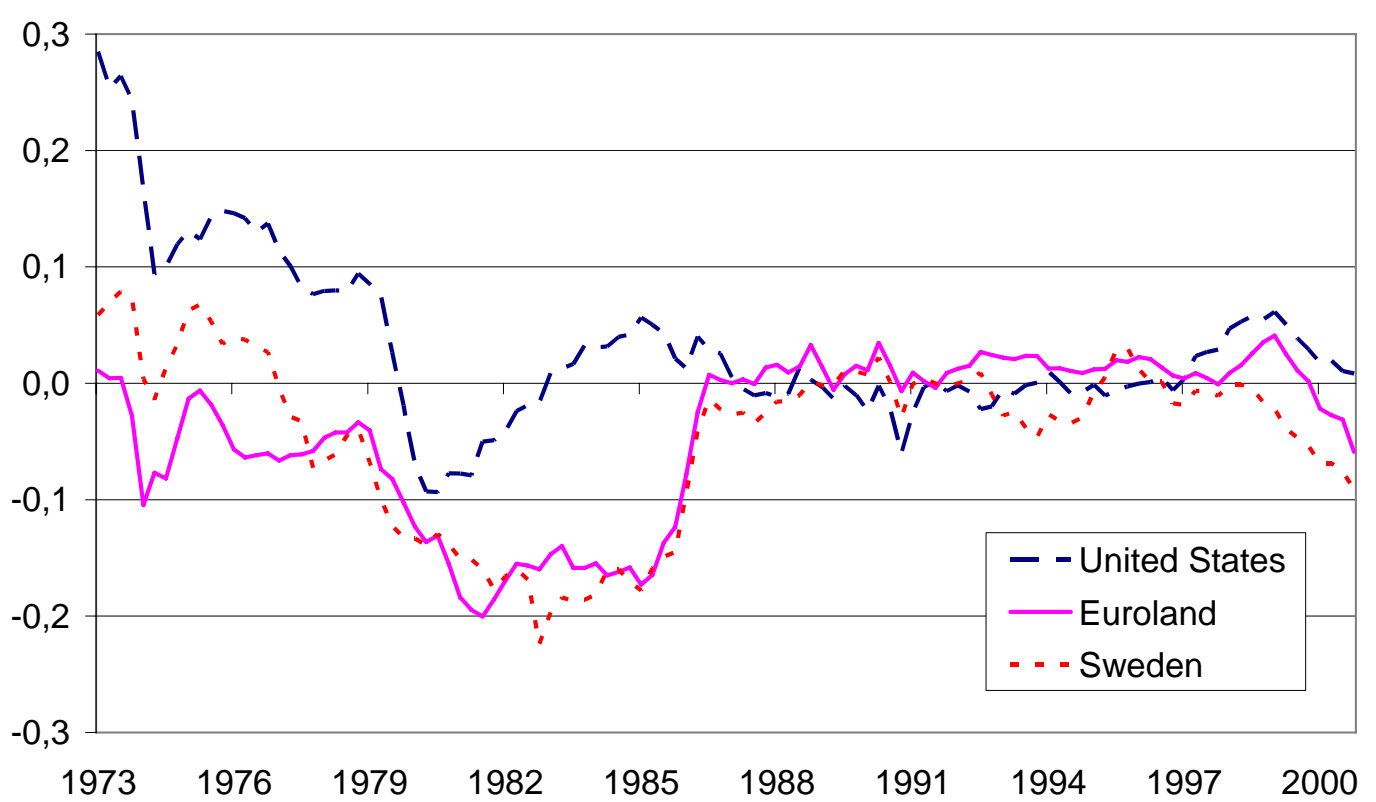

Figure 10. Quarterly change in fraction of savers

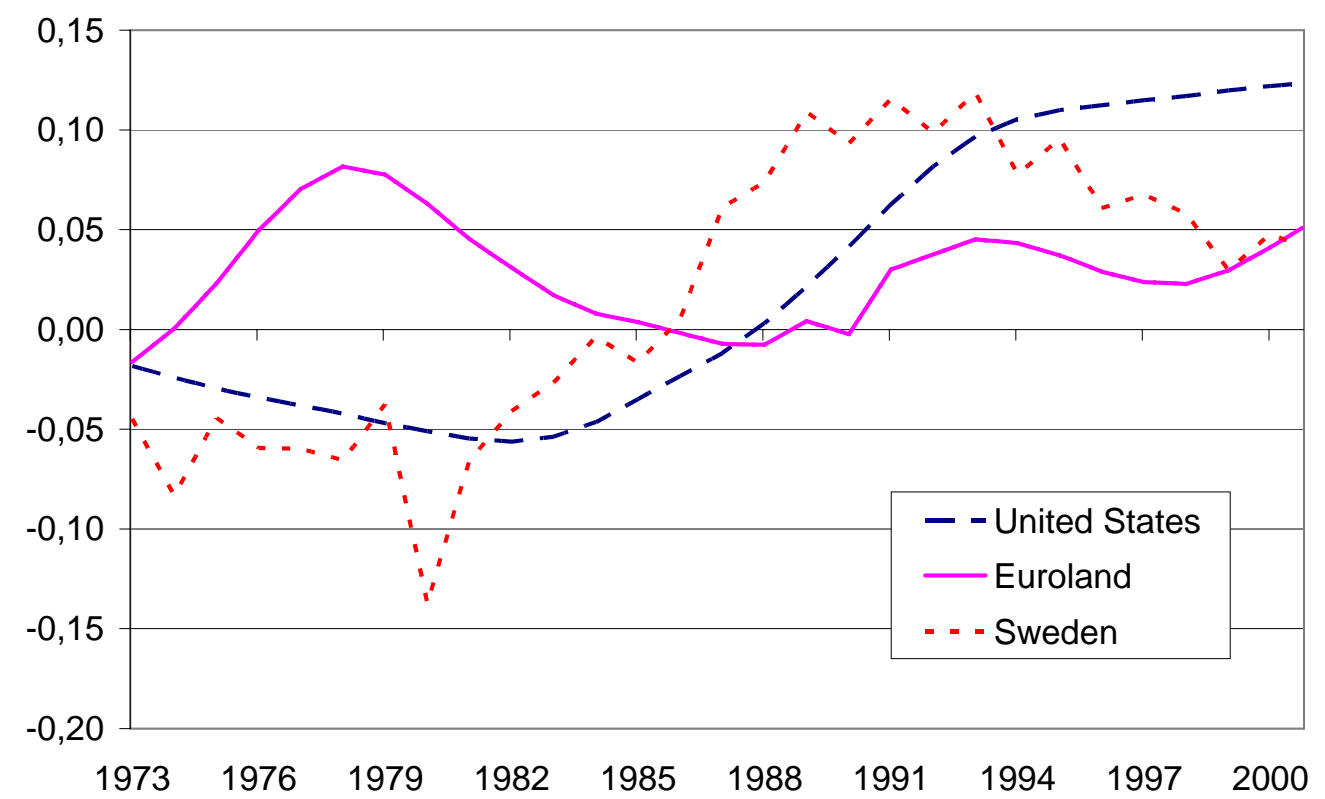


Figure 11. Structural budget deficits (percent of potential GDP)

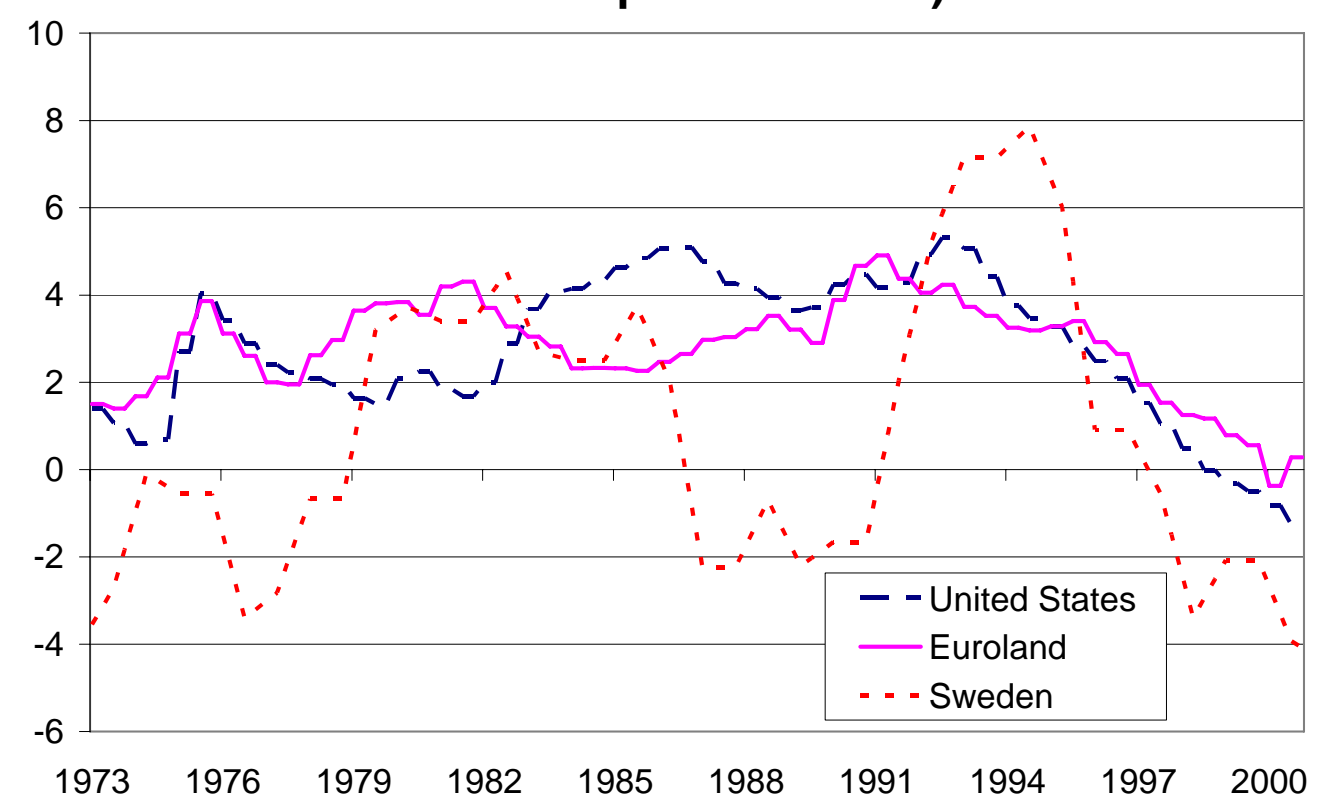

Figure 12. The U.S. cycle

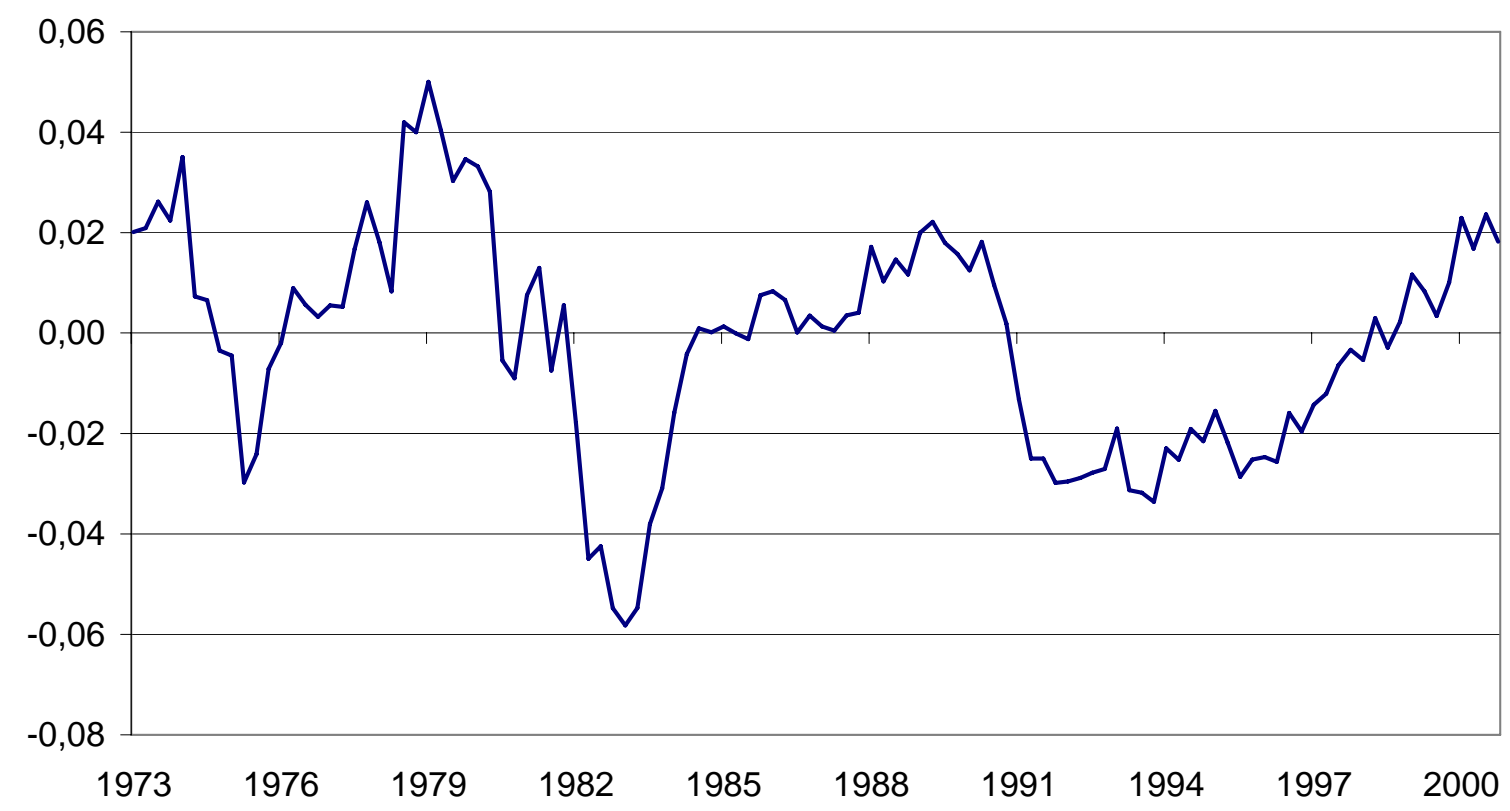


Figure 13. The Euroland cycle

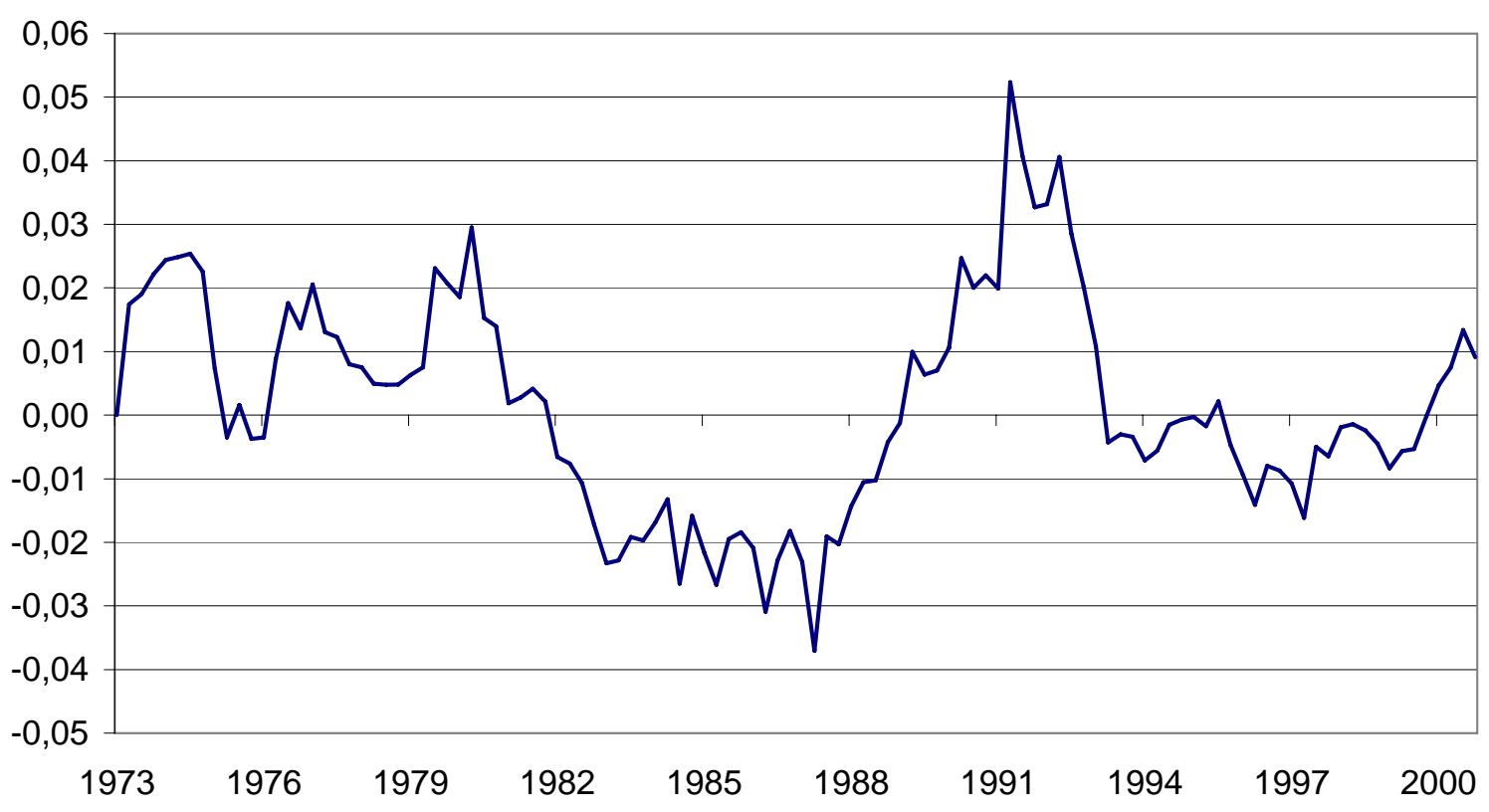

Figure 14. The Swedish cycle

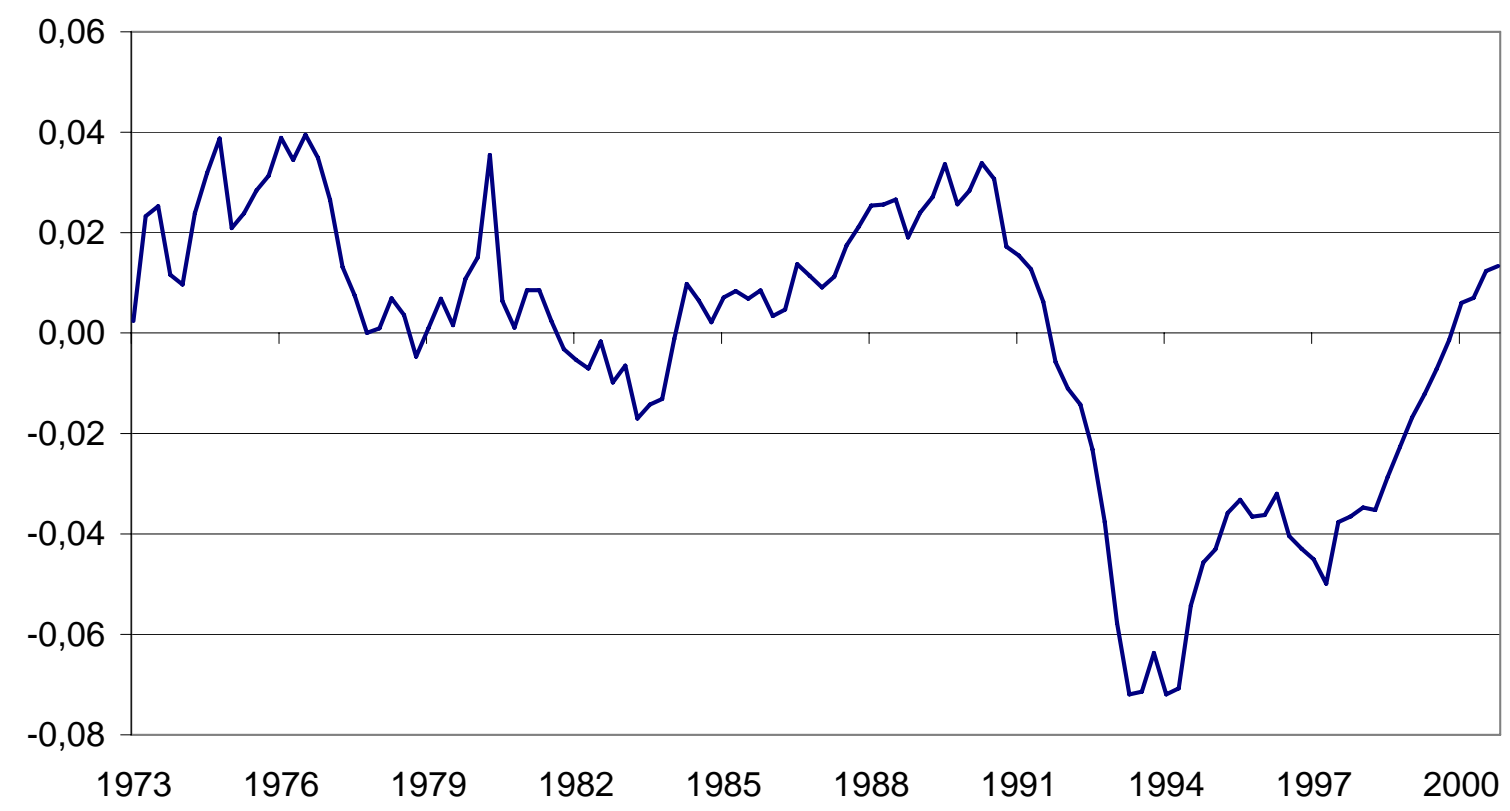


Figure 15. Real SEK/USD and long-run relations

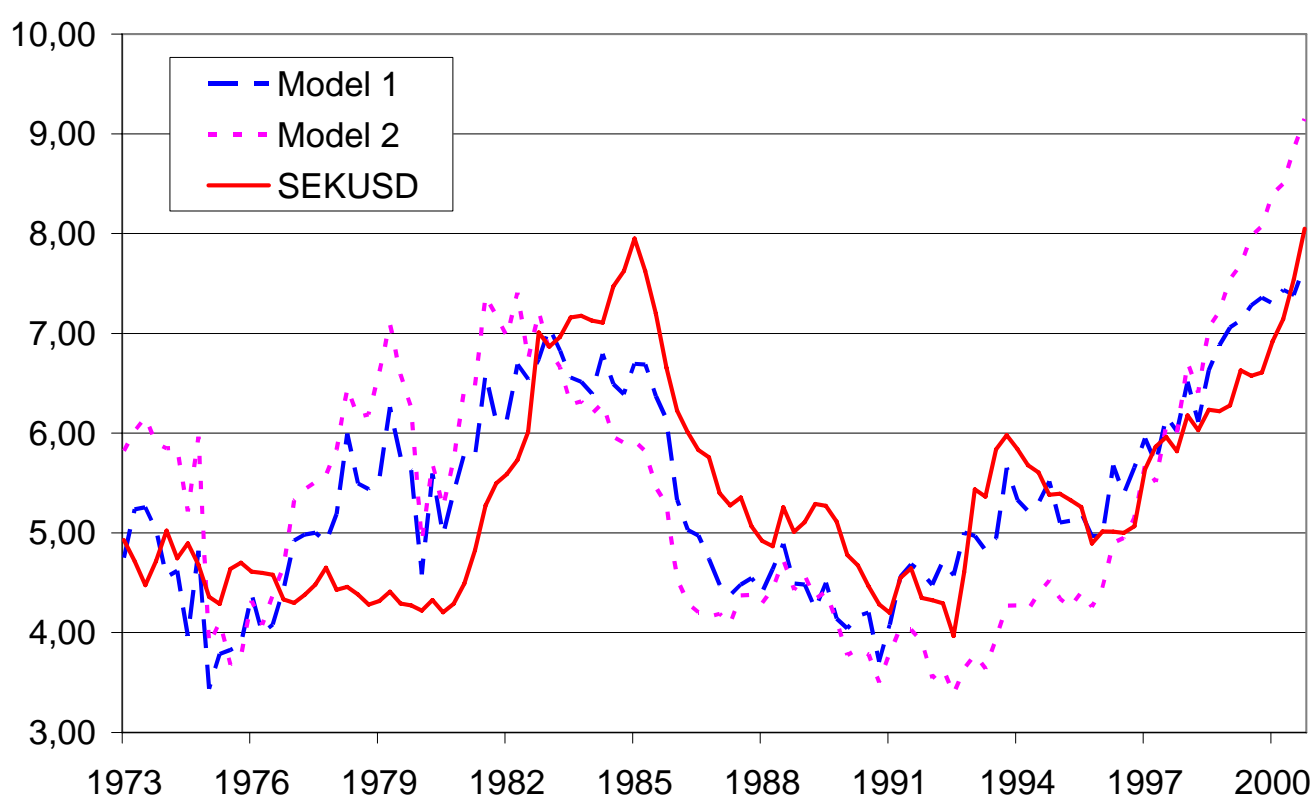

Figure 16. Real SEKIEUR and long-run relations

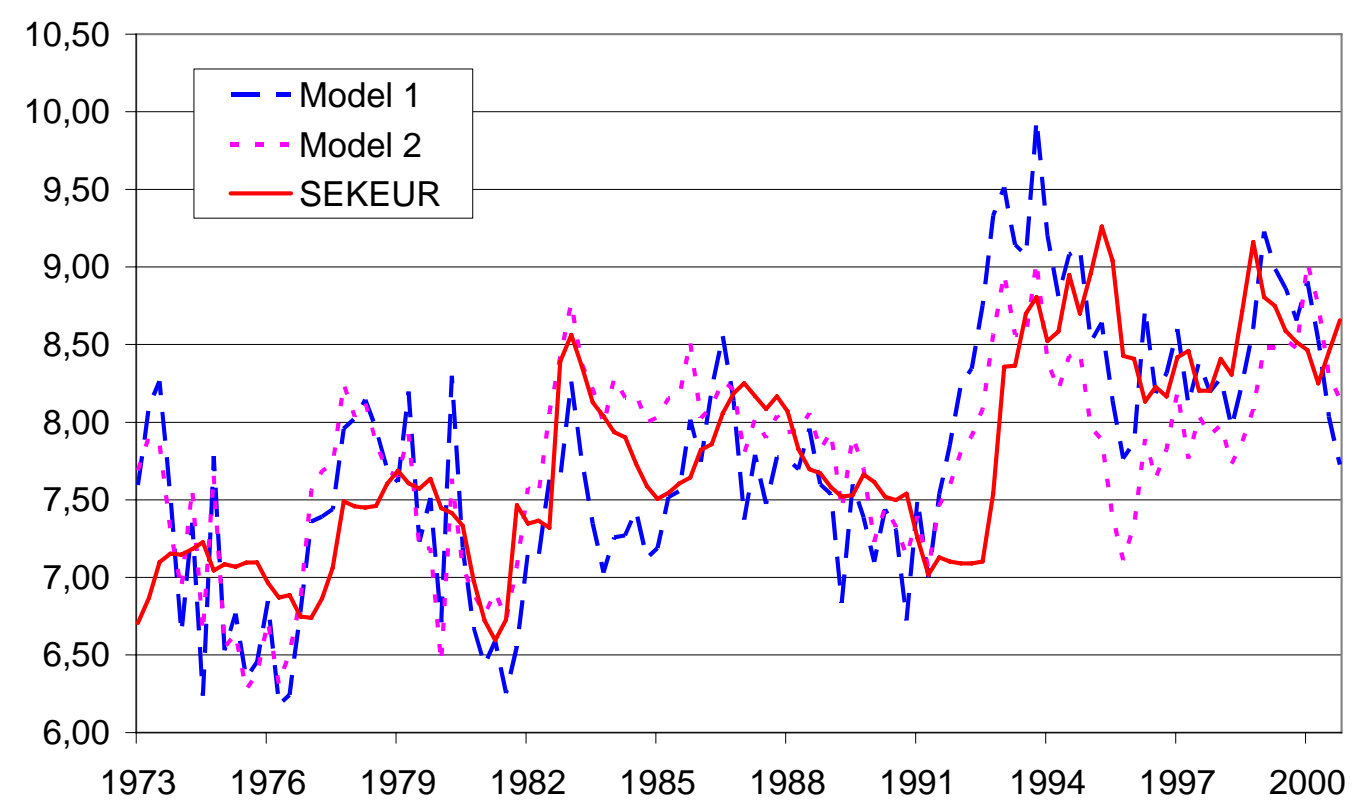


Figure 17. Real USD/EUR and long-run relations

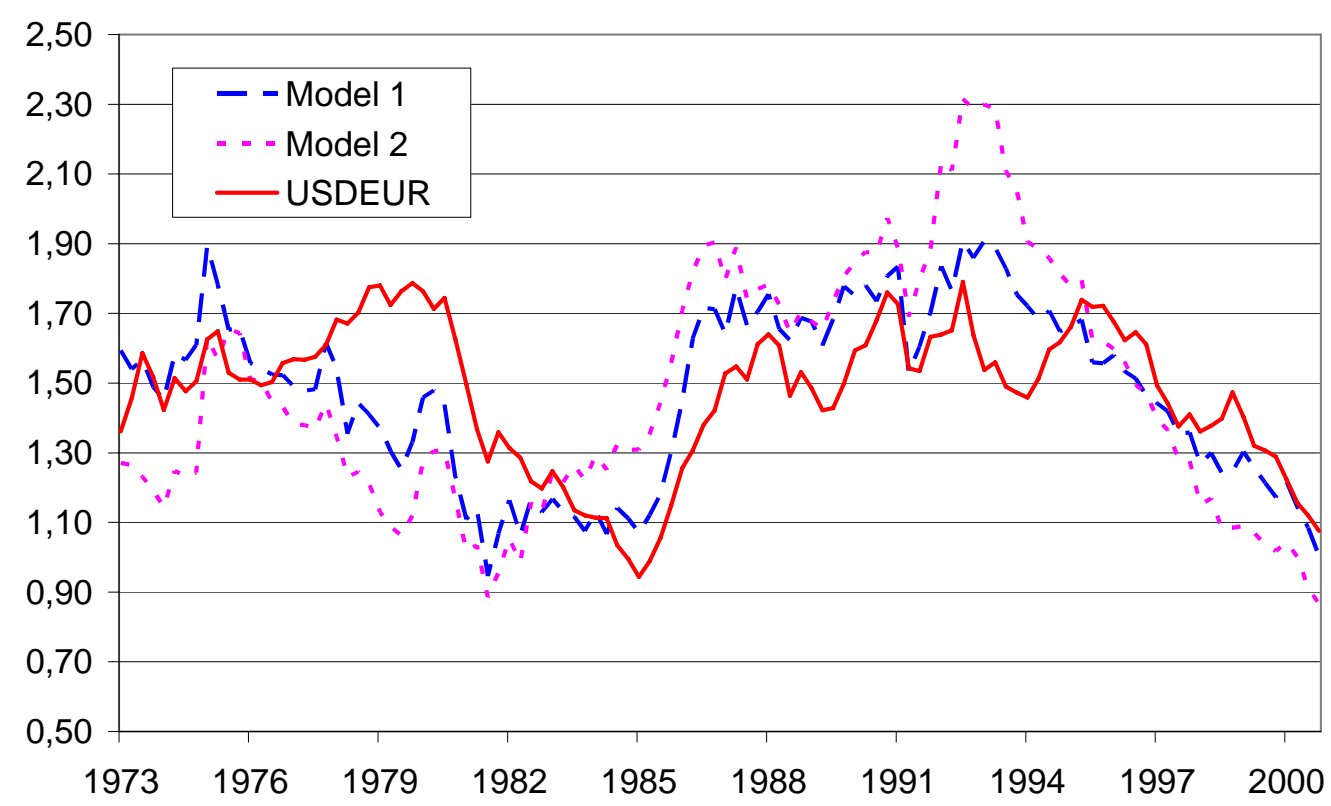

Figure 18. Real SEK/USD and forecast 2001:1 - 2005:4

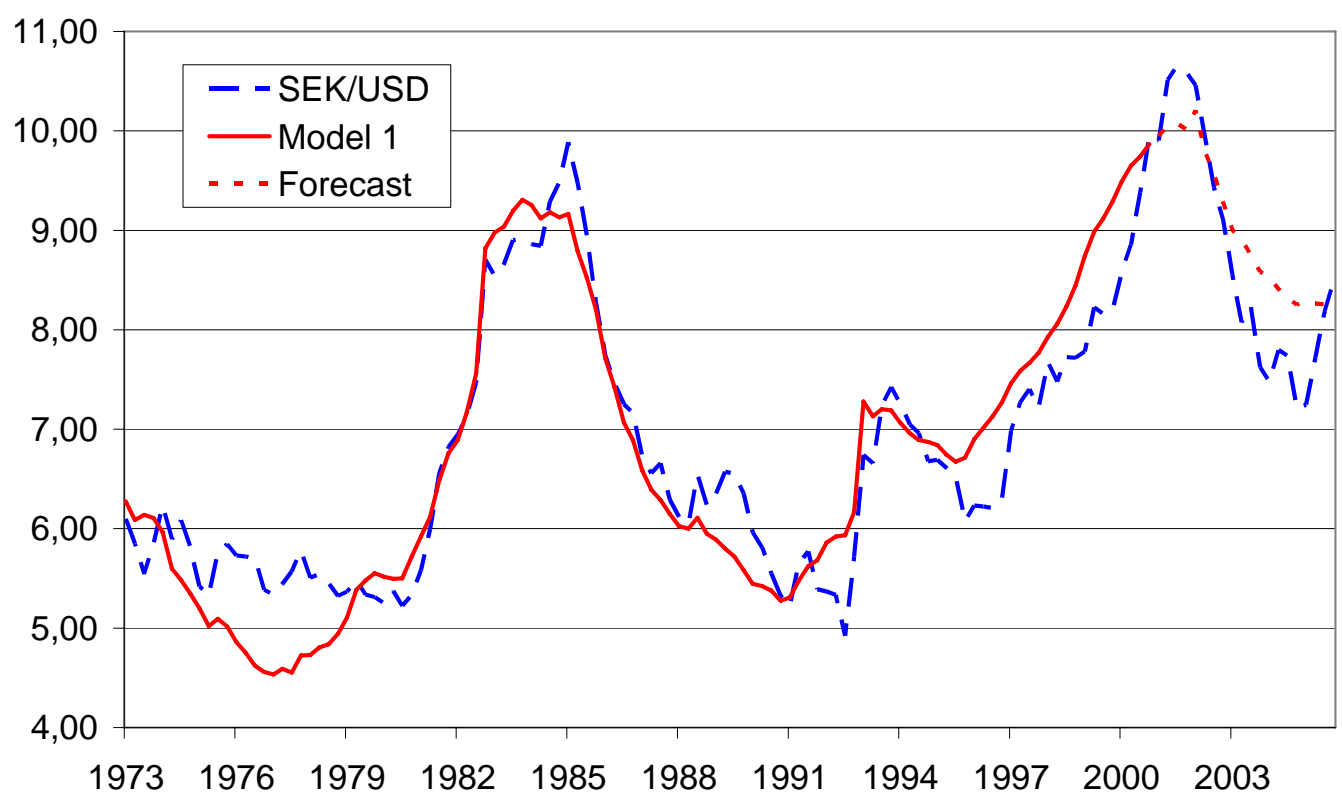


Figure 19. Real SEK/EUR and forecast 2001:1 - 2005:4

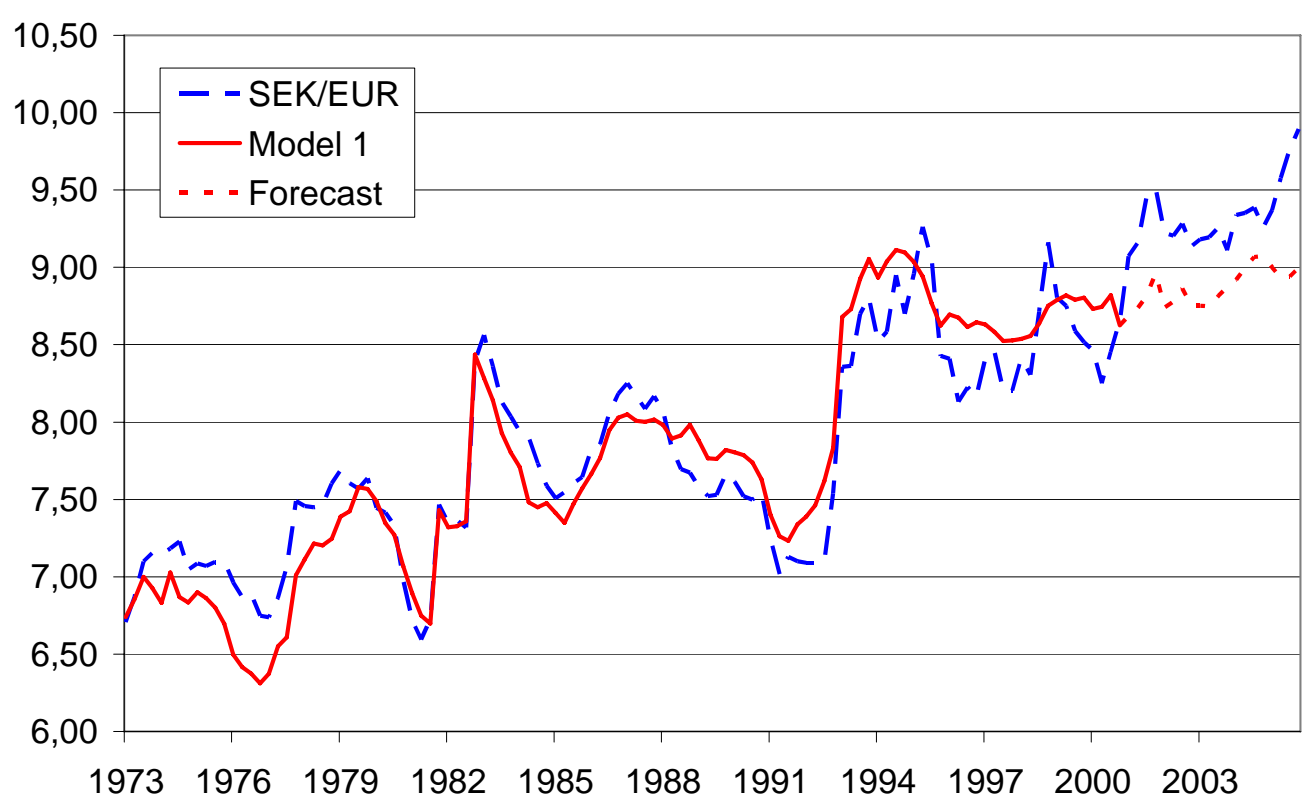

Figure 20. Real EUR/USD and forecast 2001:1 - 2005:4

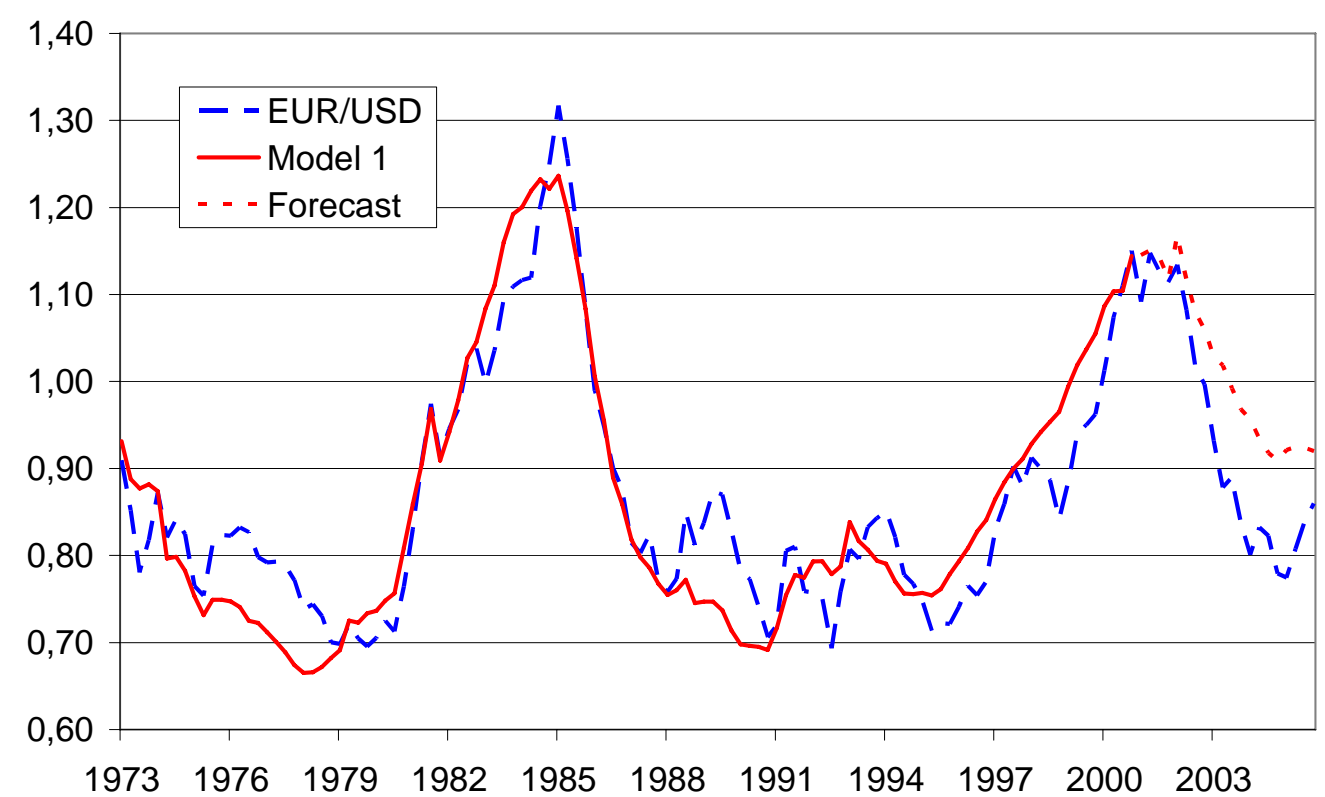




\section{Earlier Working Papers:}

For a complete list of Working Papers published by Sveriges Riksbank, see www.riksbank.se

Evaluating Implied RNDs by some New Confidence Interval Estimation Techniques

by Magnus Andersson and Magnus Lomakka....

Taylor Rules and the Predictability of Interest Rates

by Paul Söderlind, Ulf Söderström and Anders Vredin ......................................................... 2003:147

Inflation, Markups and Monetary Policy

by Magnus Jonsson and Stefan Palmqvist.....

Financial Cycles and Bankruptcies in the Nordic Countries by Jan Hansen........................................ 2003:149

Bayes Estimators of the Cointegration Space by Mattias Villani .................................................. 2003:150

Business Survey Data: Do They Help in Forecasting the Macro Economy?

by Jesper Hansson, Per Jansson and Mårten Löf

The Equilibrium Rate of Unemployment and the Real Exchange Rate:

An Unobserved Components System Approach by Hans Lindblad and Peter Sellin ........................ 2003:152

Monetary Policy Shocks and Business Cycle Fluctuations in a

Small Open Economy: Sweden 1986-2002 by Jesper Lindé

Bank Lending Policy, Credit Scoring and the Survival of Loans by Kasper Roszbach .......................... 2003:154

Internal Ratings Systems, Implied Credit Risk and the Consistency of Banks' Risk

Classification Policies by Tor Jacobson, Jesper Lindé and Kasper Roszbach .................................. 2003:155

Monetary Policy Analysis in a Small Open Economy using Bayesian Cointegrated

Structural VARs by Mattias Villani and Anders Warne

Indicator Accuracy and Monetary Policy: Is Ignorance Bliss? by Kristoffer P. Nimark ........................ 2003:157

Intersectoral Wage Linkages in Sweden by Kent Friberg .......................................................... 2003:158

Do Higher Wages Cause Inflation? by Magnus Jonsson and Stefan Palmqvist ............................. 2004:159

Why Are Long Rates Sensitive to Monetary Policy by Tore Ellingsen and Ulf Söderström .................. 2004:160

The Effects of Permanent Technology Shocks on Labor Productivity

and Hours in the RBC model by Jesper Lindé........................................................................ 2004:161

Credit Risk versus Capital Requirements under Basel II: Are SME Loans and Retail

Credit Really Different? by Tor Jacobson, Jesper Lindé and Kasper Roszbach

Exchange Rate Puzzles: A Tale of Switching Attractors

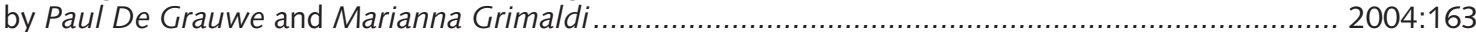

Bubbles and Crashes in a Behavioural Finance Model

by Paul De Grauwe and Marianna Grimaldi.

Multiple-Bank Lending: Diversification and Free-Riding in Monitoring

by Elena Carletti, Vittoria Cerasi and Sonja Daltung.............................................................. 2004:165

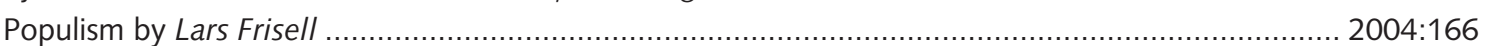

Monetary Policy in an Estimated Open-Economy Model with Imperfect Pass-Through

by Jesper Lindé, Marianne Nessén and Ulf Söderström

Is Firm Interdependence within Industries Important for Portfolio Credit Risk?

by Kenneth Carling, Lars Rönnegård and Kasper Roszbach

$2004: 168$

How Useful are Simple Rules for Monetary Policy? The Swedish Experience

by Claes Berg, Per Jansson and Anders Vredin

The Welfare Cost of Imperfect Competition and Distortionary Taxation

by Magnus Jonsson

A Bayesian Approach to Modelling Graphical Vector Autoregressions

by Jukka Corander and Mattias Villani

Do Prices Reflect Costs? A study of the price- and cost structure of retail payment

services in the Swedish banking sector 2002 by Gabriela Guibourg and Biörn Segendorf

Excess Sensitivity and Volatility of Long Interest Rates: The Role of Limited

Information in Bond Markets by Meredith Beechey.

State Dependent Pricing and Exchange Rate Pass-Through

by Martin Flodén and Fredrik Wilander.

The Multivariate Split Normal Distribution and Asymmetric Principal

Components Analysis by Mattias Villani and Rolf Larsson

Firm-Specific Capital, Nominal Rigidities and the Business Cycle

by David Altig, Lawrence Christiano, Martin Eichenbaum and Jesper Lindé

Estimation of an Adaptive Stock Market Model with Heterogeneous Agents by Henrik Amilon ........ 2005:177

Some Further Evidence on Interest-Rate Smoothing: The Role of Measurement

Errors in the Output Gap by Mikael Apel and Per Jansson...... 
Bayesian Estimation of an Open Economy DSGE Model with Incomplete Pass-Through by Malin Adolfson, Stefan Laséen, Jesper Lindé and Mattias Villani

Are Constant Interest Rate Forecasts Modest Interventions? Evidence from an Estimated Open Economy DSGE Model of the Euro Area by Malin Adolfson, Stefan Laséen, Jesper Lindé and Mattias Villani ....

Inference in Vector Autoregressive Models with an Informative

Prior on the Steady State by Mattias Villani

Bank Mergers, Competition and Liquidity by Elena Carletti, Philipp Hartmann and Giancarlo Spagnolo

Testing Near-Rationality using Detailed Survey Data

by Michael F. Bryan and Stefan Palmqvist....

Exploring Interactions between Real Activity and the Financial Stance

by Tor Jacobson, Jesper Lindé and Kasper Roszbach

Two-Sided Network Effects, Bank Interchange Fees,

and the Allocation of Fixed Costs by Mats A. Bergman

Trade Deficits in the Baltic States: How Long Will the Party Last?

by Rudolfs Bems and Kristian Jönsson

Real Exchange Rate and Consumption Fluctuations follwing Trade Liberalization

by Kristian Jönsson

Modern Forecasting Models in Action: Improving Macroeconomic Analyses at Central Banks

by Malin Adolfson, Michael K. Andersson, Jesper Lindé, Mattias Villani and Anders Vredin.....

Bayesian Inference of General Linear Restrictions on the Cointegration Space by Mattias Villani

2005:189

Forecasting Performance of an Open Economy Dynamic Stochastic General Equilibrium Model by Malin Adolfson, Stefan Laséen, Jesper Lindé and Mattias Villani

Forecast Combination and Model Averaging using Predictive Measures

by Jana Eklund and Sune Karlsson

Swedish Intervention and the Krona Float, 1993-2002

by Owen F. Humpage and Javiera Ragnartz .... 
veriges Riksbank

Visiting address: Brunkebergs torg 11

Mail address: se-103 37 Stockholm

Website: www.riksbank.se 